Natural and Accelerated Bioremediation Research (NABIR) Field Research Center (FRC) Management Plan

December 2001

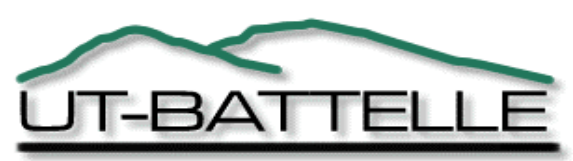

Management Contractor for DOE's Oak Ridge National Laboratory 


\section{DOCUMENT AVAILABILITY}

Reports produced after January 1, 1996, are generally available free via the U.S. Department of Energy (DOE) Information Bridge.

Web site http://www.osti.gov/bridge

Reports produced before January 1, 1996, may be purchased by members of the public from the following source.

National Technical Information Service

5285 Port Royal Road

Springfield, VA 22161

Telephone 703-605-6000 (1-800-553-6847)

TDD 703-487-4639

Fax 703-605-6900

E-mail info@ntis.fedworld.gov

Web site http://www.ntis.gov/support/ordernowabout.htm

Reports are available to DOE employees, DOE contractors, Energy Technology Data Exchange (ETDE) representatives, and International Nuclear Information System (INIS) representatives from the following source.

Office of Scientific and Technical Information

P.O. Box 62

Oak Ridge, TN 37831

Telephone 865-576-8401

Fax 865-576-5728

E-mail reports@adonis.osti.gov

Web site http://www.osti.gov/contact.html

This report was prepared as an account of work sponsored by an agency of the United States Government. Neither the United States Government nor any agency thereof, nor any of their employees, makes any warranty, express or implied, or assumes any legal liability or responsibility for the accuracy, completeness, or usefulness of any information, apparatus, product, or process disclosed, or represents that its use would not infringe privately owned rights. Reference herein to any specific commercial product, process, or service by trade name, trademark, manufacturer, or otherwise, does not necessarily constitute or imply its endorsement, recommendation, or favoring by the United States Government or any agency thereof. The views and opinions of authors expressed herein do not necessarily state or reflect those of the United States Government or any agency thereof. 
Environmental Sciences Division

\title{
NATURAL AND ACCELERATED BIOREMEDIATION RESEARCH (NABIR) FIELD RESEARCH CENTER (FRC) MANAGEMENT PLAN
}

\author{
D. B. Watson, H. D. Quarles \\ Environmental Sciences Division \\ Oak Ridge National Laboratory
}

Date Published: December 2001

Prepared for

U.S. Department of Energy

Office of Biological and Environmental Research

Budget Activity Number: KP 1301010

Prepared by

OAK RIDGE NATIONAL LABORATORY

Oak Ridge, Tennessee 37831

managed by

UT-BATTELLE, LLC

for the

U.S. DEPARTMENT OF ENERGY

under contract DE-AC05-00OR22725 


\section{CONTENTS}

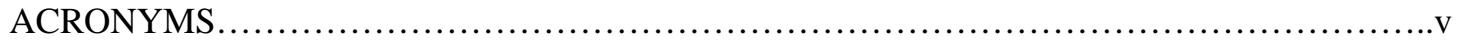

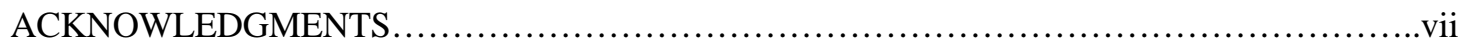

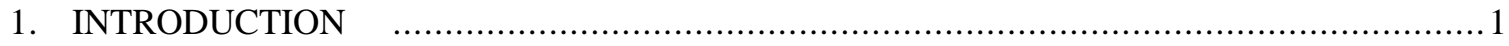

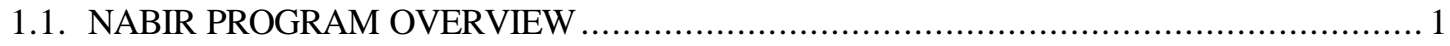

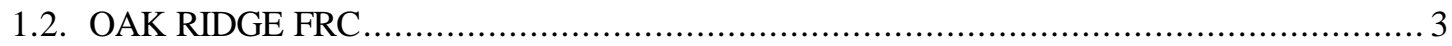

2. PURPOSE

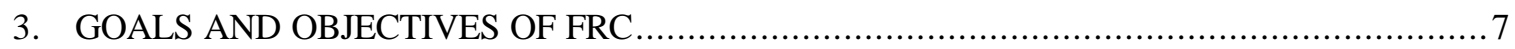

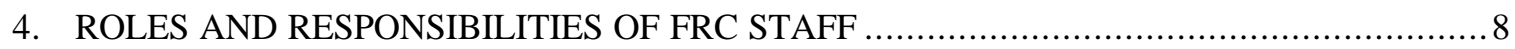

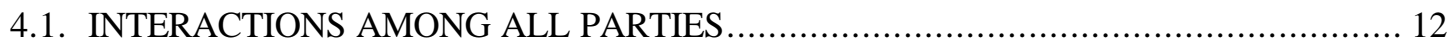

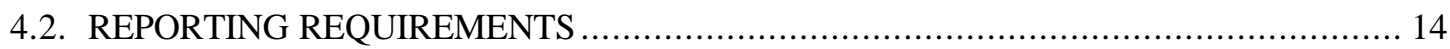

5. PROCEDURES FOR NABIR INVESTIGATORS TO INITIATE PROJECTS...................... 15

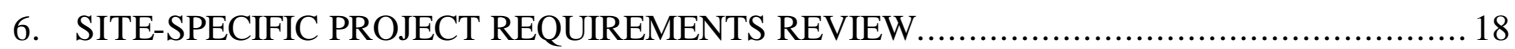

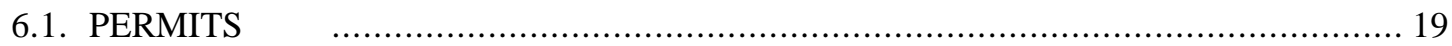

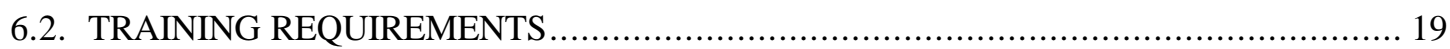

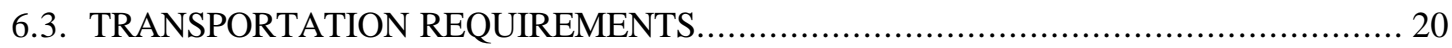

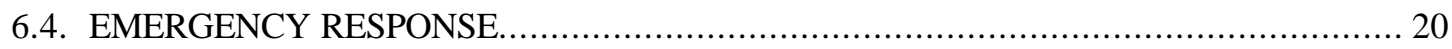

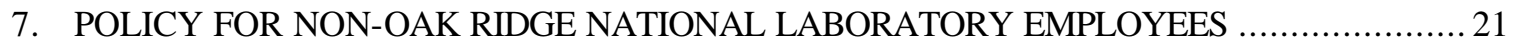

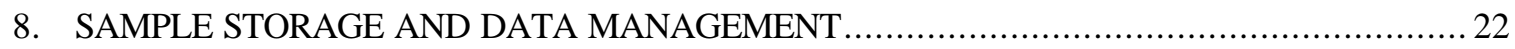

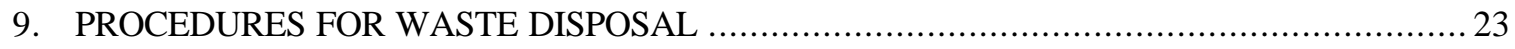

10. CONFLICT OF INTEREST AND INTELLECTUAL PROPERTY RIGHTS ........................ 24

11. CHARACTERIZATION AND RESEARCH CAMPAIGN ACTIVITIES AND PLANS..............25

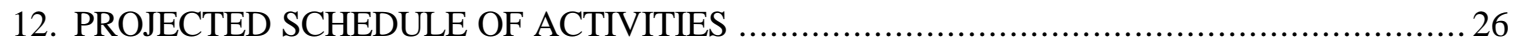

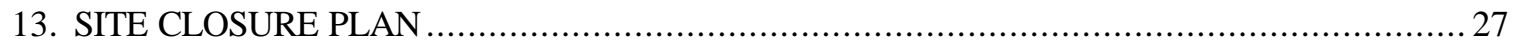

14. REFERENCES

APPENDIX A CONTACT LIST OF INDIVIDUALS AND ORGANIZATIONS IMPORTANT TO THE OPERATION OF THE FRC ...................................... 29

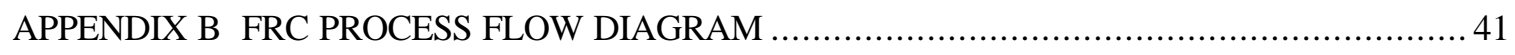

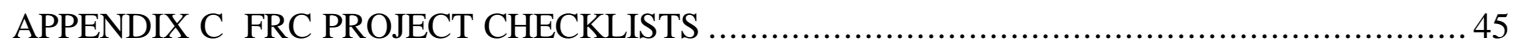




\section{ACRONYMS}

$\begin{array}{ll}\text { BASIC } & \text { Bioremediation and its Societal Implications and Concerns } \\ \text { CERCLA } & \text { Comprehensive Environmental Response, Compensation, and Liability Act } \\ \text { CFR } & \text { Code of Federal Regulations } \\ \text { DOE } & \text { Department of Energy } \\ \text { DOT } & \text { Department of Transportation } \\ \text { EPA } & \text { Environmental Protection Agency } \\ \text { ESH\&Q } & \text { Environment Safety, Health, and Quality } \\ \text { FRAP } & \text { Field Research Advisory Panel } \\ \text { FRC } & \text { Field Research Center } \\ \text { ISMS } & \text { Integrated Safety Management System } \\ \text { ITRD } & \text { Innovative Technology Remediation Demonstration } \\ \text { HASP } & \text { Health and Safety Plan } \\ \text { MOU } & \text { Memorandum of Understanding } \\ \text { NABIR } & \text { Natural and Accelerated Bioremediation Research } \\ \text { NADIMS } & \text { NABIR Data and Information Management System } \\ \text { RTDF } & \text { Remediation Technology Development Forum } \\ \text { STCG } & \text { Site Technical Coordination Group } \\ \text { TDEC } & \text { Tennessee Department of Environment and Conservation }\end{array}$




\section{ACKNOWLEDGMENTS}

This research was funded by the Natural and Accelerated Bioremediation Research (NABIR) program, Biological and Environmental Research (BER), U.S. Department of Energy. 


\section{INTRODUCTION}

The Environmental Sciences Division at Oak Ridge National Laboratory has established a Field Research Center (FRC) to support the Natural and Accelerated Bioremediation Research (NABIR) Program on the U.S. Department of Energy (DOE) Oak Ridge Reservation in Oak Ridge, Tennessee for the DOE Headquarters Office of Biological and Environmental Research within the Office of Science.

\subsection{NABIR PROGRAM OVERVIEW}

The purpose of the ten-year NABIR Program is to increase understanding of the fundamental biotic and abiotic processes involving radionuclides and heavy metals below the surface of the land, identify biotic processes that may be controlled or accelerated, and provide field-based research to understand these fundamental processes at a field level for possible use in cleaning up DOE's contaminated sites through bioremediation (DOE 1999a). Central to the overall purpose of the NABIR Program is the establishment of this FRC for long-term research on the scientific foundations underpinning bioremediation.

Bioremediation has great promise for DOE in accomplishing its environmental management and facility cleanup mission. Bioremediation is defined by the American Academy of Microbiology as "the use of living organisms to reduce or eliminate environmental hazards resulting from accumulations of toxic chemicals and other hazardous wastes" (Gibson and Sayler 1992). The NABIR Program addresses both natural bioremediation, which relies on naturally occurring microbial and plant processes, and accelerated bioremediation, which seeks to accelerate desirable processes through the addition of amendments (e.g., nutrients, electron acceptors) or microorganisms, or by manipulating physical, chemical, or hydrological processes. Bioremediation has been successfully implemented for degradation of petroleum hydrocarbons and, to a limited extent, degradation of explosives and chlorinated hydrocarbons, as well as for immobilization of toxic trace metals. However, the effectiveness of bioremediation cannot always be predicted reliably due to numerous factors ranging from lack of basic scientific knowledge to engineering limitations. More importantly, few if any investigators have addressed bioremediation of the contaminants present at DOE sites where mixtures containing chlorinated hydrocarbons, metals, radionuclides, and inorganic contaminants are common. Finally, there is general agreement among the research community that field-based research is needed to realize the full potential of bioremediation (DOE 1995).

Fundamental research funded by the NABIR Program is coordinated under the auspices of seven interrelated science-based technical program elements (DOE 1999b). A societal/legal/educational program element is concerned with investigating the societal issues and concerns associated with bioremediation. The program elements and descriptions are:

- Biotransformation and Biodegradation - Research focused on understanding the mechanisms of how microorganisms actually transform, degrade, and immobilize complex contaminant mixtures into detoxified materials.

- Community Dynamics and Microbial Ecology - Research focused on the natural ecological processes and interactions of biotic and abiotic components of microbial subsurface ecosystems in order to understand their influence on the degradation, persistence, and toxicity of mixed contaminants. 
- Biomolecular Science and Engineering - Research in molecular and structural biology focused on improving the efficiency of bioremediation activities by genetically modifying molecules and organisms to detoxify contaminants of concern to DOE.

- Biogeochemical Dynamics - Research focused on understanding the relationships among several environmental factors that interact or interfere with the survival, growth, and activity of microbial communities and their ability to bioremediate contaminants. The environmental factors are related to the dynamic relationships among geochemical, geological, hydrological, and microbial processes.

- Assessment - Research focused on developing methods to measure, monitor, and characterize the success of bioremediation processes and the rates at which they work.

- Acceleration - Research focused on augmenting or accelerating the processes of bioremediation using both natural and engineered methods. The microbial degradation activity might be enhanced by altering the flow and transport of nutrients and microorganisms. This element would develop effective methods for accelerating and optimizing bioremediation rates.

- System Engineering, Integration, Prediction, and Optimization - Research focused on integrating the results of all of the program elements and on synthesizing the information so that the effectiveness of bioremediation can be predicted and optimized.

- Bioremediation and its Societal Implications and Concerns (BASIC Element) - Research focused on identifying the ethical, legal, and societal issues relevant to bioremediation; addressing the educational needs, intellectual property issues, regulatory and other legal issues, and the societal concerns associated with the NABIR Program, and supporting education and public outreach activities.

Five of the science elements study the biology of the microorganisms, their ecology and physical environment, their effects on various contaminants, and various mechanisms to enhance or accelerate their bioremediative processes. Another element provides the means to analyze and quantify these processes, and the last scientific element is designed to integrate the research results towards developing predictive models.

A full understanding of the natural processes involved in natural and accelerated bioremediation depends on the ability to build on laboratory experimentation by directly investigating phenomena in the field and conducting field experiments. Thus, the primary purpose of the FRC is to move laboratory-based research, conducted under each of the elements of the NABIR Program, to the field (DOE 1999a). In addition, by making use of FRC field sites, the NABIR Program helps in the development and training of interdisciplinary teams of microbiologists, geochemists, geologists, engineers, drilling specialists and others in field aspects of bioremediation. Results from research conducted at the FRC will also be applicable to waste management and minimization efforts such as the design and operation of bioreactors to treat a broad spectrum of dilute and concentrated waste streams from ongoing and past DOE operations (DOE 1995).

Specifically, the strategic goals of the NABIR Program are to provide the fundamental science to achieve the following goals (DOE 1999c):

- Develop cost-effective bioremediation approaches for radionuclides and heavy metals and mixtures of contaminants containing metals and radionuclides in the subsurface at DOE sites;

- Understand intrinsic bioremediation as well as opportunities for manipulated, accelerated bioremediation using chemical/microbial amendments;

- Integrate bioremediation with conventional physical-chemical remediation to accelerate site cleanup;

- Allow regulators, local communities, and other stakeholders the opportunity to evaluate bioremediation; 
- $\quad$ Provide rational, quantitative "end points" for remediation for regulatory compliance monitoring; and

- Coordinate research activities with other DOE research programs (e.g., Environmental Management Science Program, EM-50 Focus Areas, Microbial Geonome Program) and with the DOE Office of Environmental Management and other customers.

Establishing the FRC for long-term research on the scientific foundations underpinning bioremediation is an important component in meeting these goals. Further, the FRC will play a critical role by ensuring that knowledge gained from NABIR research will be used to help solve DOE's environmental management problems. Locating the FRC at a DOE facility provides ongoing opportunities for a two-way transfer of information between the environmental management problem holders and the research community. Researchers will learn more about site-specific needs for fundamental and applied research. Site personnel responsible for cleanup will keep abreast of the latest scientific developments and new opportunities for applying bioremediation.

\subsection{OAK RIDGE FRC}

The FRC lies within the Y-12 National Security Complex area of responsibility on the Oak Ridge Reservation. The Y-12 National Security Complex is located in Bear Creek Valley adjacent to the city of Oak Ridge. The FRC provides a site for investigators in the NABIR program to conduct research and obtain samples related to in situ bioremediation. NABIR is a ten-year program designed to increase the understanding of fundamental biogeochemical processes that would allow the use of bioremediation approaches for use in cleaning up DOE's contaminated legacy waste sites. The FRC is integrated with existing and future laboratory and field research and provides a means of examining the biogeochemical processes that influence bioremediation under controlled small-scale field conditions.

The Oak Ridge Reservation is the site of three major DOE facilities administered by DOE's Oak Ridge Operations Office-Oak Ridge National Laboratory, Y-12 National Security Complex, and East Tennessee Technology Park, formerly known as the K-25 Site. Figure 1.1 shows the general location of the FRC, surrounding counties, and the three DOE facilities within the Oak Ridge and Knoxville region.

The Oak Ridge Reservation was placed on the Comprehensive Environmental Response, Compensation, and Liability Act (CERCLA) National Priorities List in 1989. Remediation efforts on the Oak Ridge Reservation, including individual sites in Bear Creek Valley, are governed by the Federal Facility Agreement among DOE, Region IV of the U.S. Environmental Protection Agency (EPA), and the Tennessee Department of Environment and Conservation (TDEC). Subsequently, the Remedial Investigation/Feasibility Study for the Bear Creek Watershed was performed to address contamination associated with former waste disposal activities in Bear Creek Valley. The Record of Decision was signed in May of 2000.

The Y-12 National Security Complex is administered through the DOE Headquarters Defense Programs Office. It is operated by BWXT Y-12, the Management and Operations contractor. Bechtel Jacobs Company is the Management and Integration contractor responsible for environmental management activities (administered through DOE Headquarters Office of Environmental Management) conducted on the Oak Ridge Reservation. UT-Battelle is the Management and Operations contractor for Oak Ridge National Laboratory, which is administered through DOE Headquarters Office of Science.

The FRC includes a 243-acre (98-ha), previously disturbed contaminated area to be used for conducting experiments on a plume of contaminated groundwater. It also includes a 404-acre (163-ha) background area (Fig. 1.1) that provides for comparison studies in an uncontaminated area, and ancillary structures located within a 3.2-mile $(5.2-\mathrm{km})$ radius of each other on the Oak Ridge Reservation. The contaminated site 
includes the commingled groundwater plume found in the shallow unconsolidated sediments $(<10 \mathrm{~m}$ depth $)$, in the Nolichucky Shale, and in the Maynardville Limestone that originated from a combination of Y-12's S-3 Waste Disposal Ponds and Bone Yard/Burn Yard. The initial focus of NABIR investigations, however, is on the easily accessible shallow unconsolidated sediments that overlie the Nolichucky Shale. Contaminants in this plume and in the shallow saturated and unsaturated soils include uranium, Tc-99, strontium metal, nitrate, barium, cadmium, volatile organic contaminants and other inorganics and radionuclides of interest to NABIR investigators. Initially, test plots of approximately one-half acre situated in proximity to the S-3 Ponds Site parking lot are to be used. As the course of NABIR investigations proceeds, other test plots are to be used farther down Bear Creek Valley.

The contaminated and background areas are located in Bear Creek Valley (Fig. 1.1). Bear Creek Valley is approximately 10 miles (16 kilometers $[\mathrm{km}]$ ) long and extends from the eastern end of the Y-12 National Security Complex to the Clinch River on the west. Bear Creek is a tributary to East Fork Poplar Creek, which drains into the Clinch River at the East Tennessee Technology Park. Except for the extreme eastern end of the contaminated portion of the FRC, the area is outside of any security fences adjacent to public use roads, but protected from unwarranted passersby.

No new construction was required to establish and maintain the FRC although field trailers were relocated to both the contaminated and background areas. Existing ancillary facilities (e.g., equipment sheds) are used to support FRC activities. Staff and researchers use existing facilities at Oak Ridge National Laboratory, including offices and research laboratories. The FRC is of sufficient size to accommodate multi-investigator studies over the ten-year lifespan of the NABIR Program. 

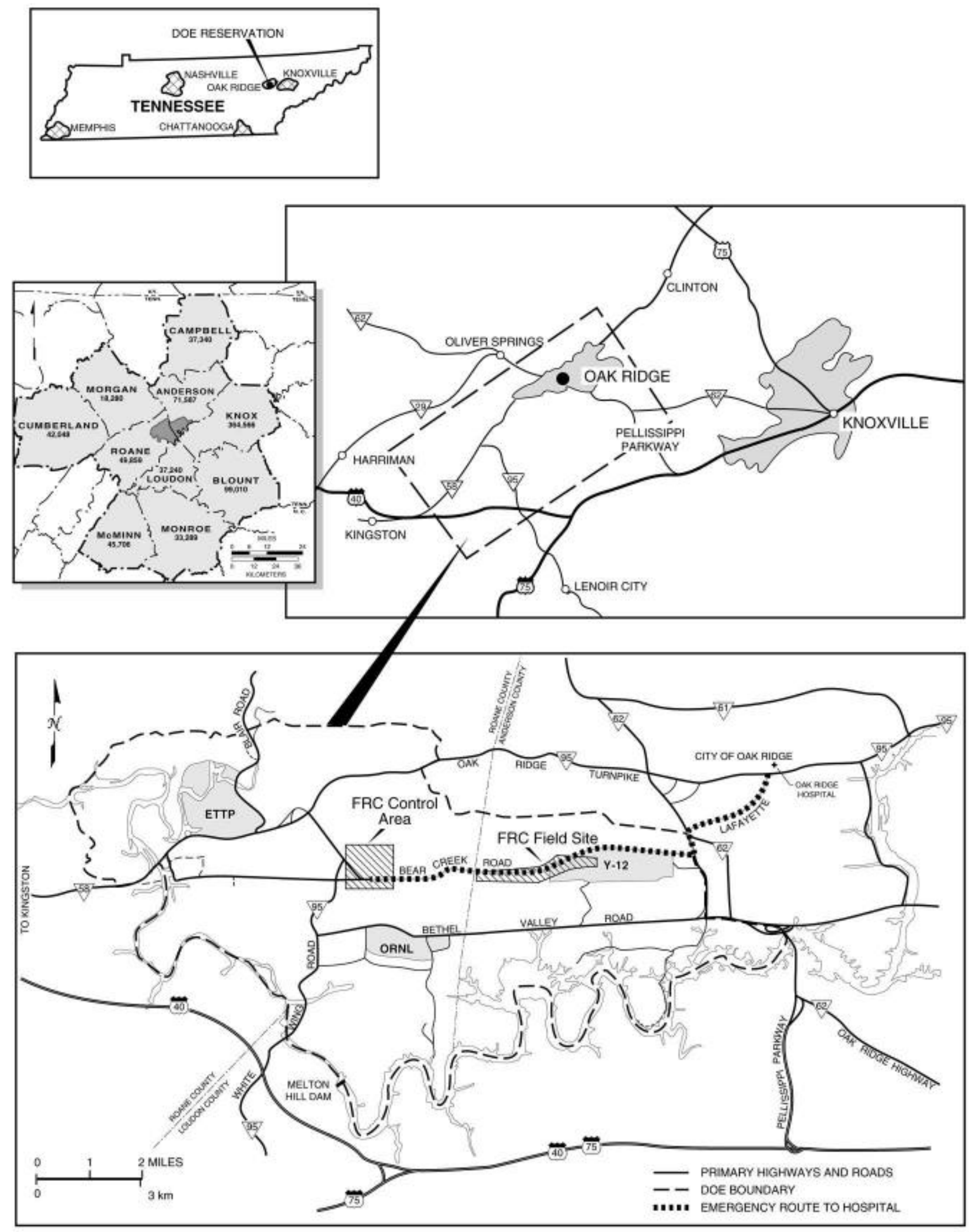

Fig. 1.1. Location of the FRC in Oak Ridge, Tennessee. 


\section{PURPOSE}

The purpose of the FRC is to provide a site for investigators in the NABIR Program to conduct research and obtain samples related to in situ bioremediation in order to increase the understanding of fundamental biogeochemical processes that will allow the use of bioremediation approaches for cleaning up DOE's legacy waste sites contaminated with metals and radionuclides. The FRC is being integrated with existing and future laboratory and field research to provide a means of examining fundamental biogeochemical processes that influence bioremediation approaches under field conditions. The FRC is operated by Oak Ridge National Laboratory's Environmental Sciences Division.

The purpose of this FRC Management Plan is to outline procedures to facilitate the scientific approach to research at the FRC, and the approach to ensuring Environment, Safety and Health compliance. This plan also provides a list of the roles and responsibilities of individuals and organizations involved with research activities at the FRC.

This FRC Management Plan tiers from the Office of Biological and Environmental Research NABIR Program Plan (DOE 1995), and is one of a set of high-level planning documents developed by FRC staff members that govern the operation of the FRC. These include the following plans:

- Site Characterization Plan

- Quality Assurance Plan describing procedures that will be followed to assure that FRC data is of sufficient quality to meet project objectives

- $\quad$ Site-Specific Health and Safety Plan tiered from the ORNL HAZWOPER Program Manual

- Communication/Community Interaction Plan detailing interactions with community and other stakeholder groups

Together, these high-level plans form a "road map" for conduct of operations at the FRC for both the scientific research to be conducted, as well as the commitments to Environment, Safety and Health.

In addition to these plans, detailed project-specific work plans will be prepared describing each work phase to be conducted at the FRC. These work plans will be prepared by FRC staff members or NABIR investigators depending on the source of project funding and who is responsible for executing the project.

Specific Environment, Safety, Health, and Quality (ESH\&Q) requirements for activities conducted at the FRC are determined on a project-by-project basis through individual Integrated Safety Management System (ISMS) project reviews conducted in accordance with, and as described in, this FRC Management Plan. 


\section{GOALS AND OBJECTIVES OF FRC}

The FRC provides field research sites for investigator-initiated research by scientists sponsored by the NABIR Program. The FRC and supporting infrastructure are designed to facilitate long-term, interdisciplinary research and, as needed, to provide samples to individual NABIR investigators to conduct laboratory and field studies.

The FRC provides NABIR investigators with field research sites containing a spectrum of waste types and subsurface environmental media (vadose zone and saturated zone) that are representative of both background and contaminated conditions within the DOE complex. The FRC also offers a source for standardized subsurface samples for NABIR investigators, and field locations for in situ research. Field scale research at the FRC offers the investigator the opportunity to move laboratory-based research to the field, and observe and manipulate bioremediation processes involving heavy metals and radionuclides in a small-scale field setting. Data collected from research conducted at the FRC is managed in accordance with the Quality Assurance Plan to ensure consistency, and is available to NABIR researchers through the FRC Data Management System maintained by ORNL. 


\section{ROLES AND RESPONSIBILITIES OF FRC STAFF}

The FRC is staffed by an on-site FRC Manager and support staff, all of whom are ORNL employees, to help facilitate researchers' access to field locations at the DOE site, and ensure coordination of research activities and compliance with applicable state and federal law and DOE Environment, Safety, and Health requirements. Operation and management of the FRC involves interaction among various DOE, contractor, and stakeholder organizations, as well as the NABIR investigators. The roles and responsibilities of the major entities are shown in Table 4.1; contact information for individuals and organizations important to the operation of the FRC is provided in Appendix A.

The FRC Manager is an on-site research scientist experienced in field operations associated with subsurface investigations at the FRC. The FRC Manager is dedicated full-time to the FRC and supported by staff members from a variety of disciplines. Reporting to the FRC Manager on a full- or part-time basis are individuals fulfilling the following functions:

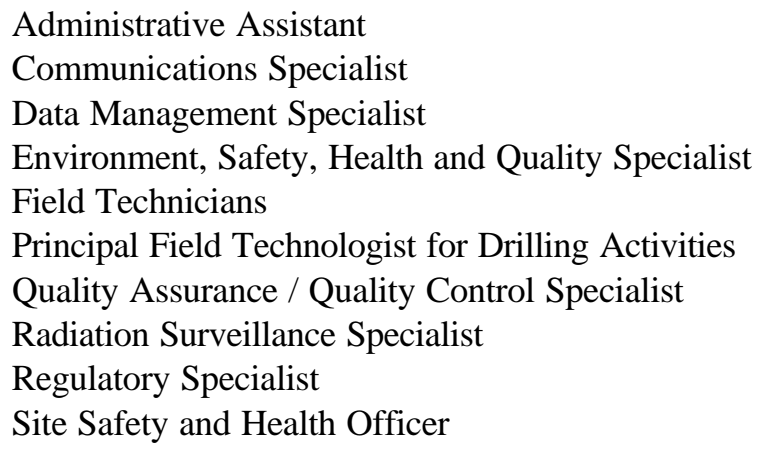

The FRC Manager and staff are responsible for record keeping, coordination of meetings, distribution of information, managing any required subcontracts such as drilling, and permit tracking as needed to support the FRC. The FRC Manager reports to the Earth and Microbial Science Section Head in the Environmental Sciences Division at Oak Ridge National Laboratory. In addition, the FRC Manager receives general direction from, and is accountable to, the DOE NABIR Field Activities Manager and receives assistance in day-to-day operations and planning activities from the NABIR Program Support Office (Table 4.1). The NABIR Program Support Office will also assist in the evaluation of potential research projects for the FRC based on the recommendations of the Field Research Advisory Panel (FRAP).

The purpose of the FRAP is to evaluate field studies proposed for the FRC and provide the NABIR Program Support Office with technical recommendations for implementation, prioritization, and optimization of these studies at the FRC. In addition, the FRAP will provide guidance that will help avoid adverse effects that could make the site unusable by other NABIR investigators (e.g., plugging of the aquifer formations by mineral precipitation or microbial biomass or promotion of long-term changes in redox conditions) or violate regulatory requirements (e.g., by inadvertently mobilizing a contaminant). The FRAP is organized through the NABIR Program Support Office at Lawrence Berkeley National Laboratory and composed of individuals of various technical backgrounds as described in Table 4.1. 


\section{Table 4.1 Roles and responsibilities of FRC entities}

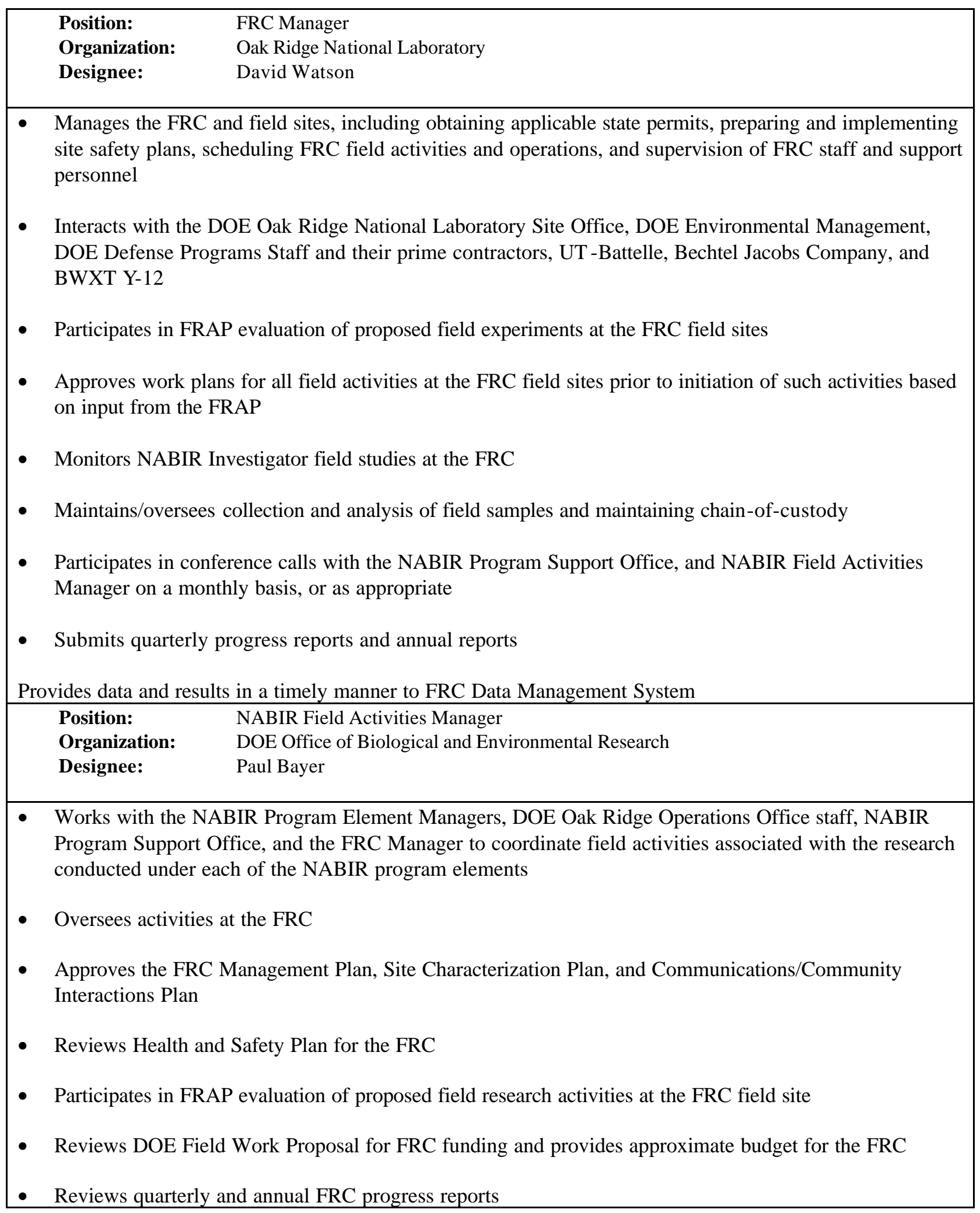


Table 4.1 (continued)

Position: NABIR Program Support Office

Organization: Lawrence Berkeley National Laboratory

Chairperson: Terry Hazen

- $\quad$ Organizes and facilitates evaluations by the FRAP

- Assists FRC Manager in preparation of planning documents

- Participates in monthly conference calls, or as needed, with FRC Manager and NABIR Field Activities Manager

- Facilitates investigators' sampling and experimental needs at the FRC

$\begin{array}{ll}\text { Position: } & \text { NABIR Program Coordinators } \\ \text { Organization: } & \text { DOE Office of Biological and Environmental Research } \\ \text { Designees: } & \text { John Houghton } \\ & \text { Anna Palmisano }\end{array}$

- Manage and coordinate activities among the following program elements:

- Biotransformation and biodegradation

- Community dynamics and microbial ecology

- Biomolecular sciences and engineering

- Biogeochemical dynamics

- Assessment

- Bacterial transport

- $\quad$ System engineering, integration, prediction and operations

- Bioremediation and its Societal Concerns (BASIC)

- $\quad$ Promote NABIR Program Element Managers' use and planning of critical field research experiments and sampling at the FRC

$\begin{array}{ll}\text { Position: } & \text { NABIR Program Elements Managers } \\ \text { Organization: } & \text { DOE Office of Biological and Environmental Research } \\ \text { Designees: } & \text { Daniel Drell } \\ & \text { John Houghton } \\ & \text { Anna Palmisano } \\ & \text { Frank Wobber }\end{array}$

- $\quad$ Provide general management and oversight (including Environment, Safety, and Health issues) of an individual program element

- $\quad$ Promote NABIR Investigator use and planning of critical field research experiments and sampling at the FRC in their program element 


\section{Table 4.1 (continued)}

Position: $\quad$ Field Research Advisory Panel

Organization: $\quad$ NABIR Program Support Office at Lawrence Berkeley National Laboratory

Designee: $\quad$ Terry Hazen

- Evaluates work plans for field research activities at the FRC and provides recommendations

- FRAP consists of FRC Manager and non-conflicted peer reviewers external to the NABIR Program Support Office staff and Lawrence Berkeley National Laboratory

Position: $\quad$ Principal Investigators

Organization: $\quad$ Universities, National Laboratories, other scientific organizations

Designees: $\quad$ Various

- $\quad$ Funded to conduct NABIR research activities

- Submit preliminary work plans and full work plans for both sampling and in situ research to the FRC Manager

- $\quad$ Provide quarterly reports to the FRC Manager on activities and necessary training certification

- $\quad$ Provide data and results in a timely manner to the FRC Manager for submittal to the FRC Data Management System
Position:
Oak Ridge Reservation Management \& Operating Contractors
Organization:
UT-Battelle (Oak Ridge National Laboratory)
BWXT Y-12
Bechtel Jacobs Company (Environmental Management)

- UT-Battelle

- $\quad$ Operates the FRC

- $\quad$ Provides FRC Manager and staff

- $\quad$ Ensures comp liance with DOE orders, State of Tennessee and federal environmental laws, Occupational Safety and Health Act, Nuclear Regulatory Commission requirements, and Department of Transportation requirements

- BWXT Y-12

- Coordinates FRC and Defense Programs (Y-12) activities

- Provides Emergency response

- $\quad$ Provides site services

- Bechtel Jacobs Company

- Coordinates FRC and Environmental Management activities

- Provides waste disposal and treatment

- Provides site access to contaminated areas 


\begin{tabular}{|c|c|c|}
\hline & & Table 4.1 (continued) \\
\hline $\begin{array}{ll}\text { Position: } & \text { DOE FRC Field Administration } \\
\text { Organization: } & \text { DOE Oak Ridge Operations Office } \\
\text { Designees: } & \text { Jason D. Darby, (Environmental Management) } \\
& \text { Sylvia J. Wolfe (ORNL Operations Division) } \\
& \text { James P. Donnelly (Technical Support Division) } \\
\end{array}$ & $\begin{array}{l}\text { Position: } \\
\text { Organization: } \\
\text { Designees: }\end{array}$ & $\begin{array}{l}\text { DOE FRC Field Administration } \\
\text { DOE Oak Ridge Operations Office } \\
\text { Jason D. Darby, (Environmental Management) } \\
\text { Sylvia J. Wolfe (ORNL Operations Division) } \\
\text { James P. Donnelly (Technical Support Division) } \\
\end{array}$ \\
\hline & 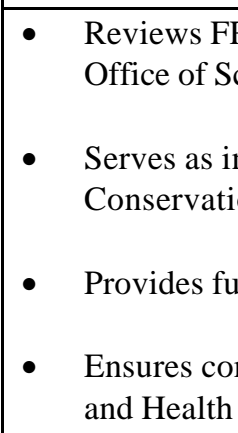 & $\begin{array}{l}\text { to ensure there are no conflicts among Environmental Management, Defense Programs, and } \\
\text { ivities } \\
\text { ith Environmental Protection Agency and Tennessee Department of Environment and } \\
\text { the FRC via UT-Battelle } \\
\text { with DOE orders, State of Tennessee and federal environmental laws, Occupational Safety } \\
\text { lear Regulatory Commission requirements, and Department of Transportation requirements }\end{array}$ \\
\hline
\end{tabular}

\subsection{INTERACTIONS AMONG ALL PARTIES}

Figure 4.1 illustrates site-specific relationships relevant to the NABIR FRC. The FRC Manager is the primary point of contact for external communications with the NABIR Field Activities Manager, and is also the primary contact for investigators interested in using the FRC.

The FRC Manager provides updates on activities and events at the FRC through quarterly and annual reports to the DOE Office of Biological and Environmental Research, DOE Oak Ridge National Laboratory Site Office, DOE Environmental Management, and DOE Defense Programs staff, and their prime contractors UT Battelle, Bechtel Jacobs Company, and BWXT Y-12. The FRC Manager also ensures they are copied on reports submitted to the DOE Office of Biological and Environmental Research. Meetings with the site contractors and DOE field office are held as needed.

Information to local regulators is communicated via DOE Environmental Management and Bechtel Jacobs Company, who have that role as part of their environmental restoration mission. As appropriate, FRC staff will attend regulator meetings and brief regulators on FRC activities. The FRC Manager and staff stay in close communication with the Site Technical Coordination Group (STCG) as they have opportunities to link FRC activities with other research and development supported by Environmental Management (the EM50 Office) or other agency offices [e.g. DOE Innovative Treatment Remediation Demonstration (ITRD), EPA Remediation Technology Development Forum (RTDF)]. Oak Ridge National Laboratory periodically updates other stakeholders as appropriate, and will be assisted in these activities by the FRC BASIC interface (currently Amy Wolfe).

The Reservation Management Organization is the primary organization for decision making with respect to use of ORR land. The Reservation Management Organization has representatives from each of the major contractors in Oak Ridge. The FRC Manager or his designee, will brief the Reservation Management Organization as needed on progress and issues related to the FRC. 


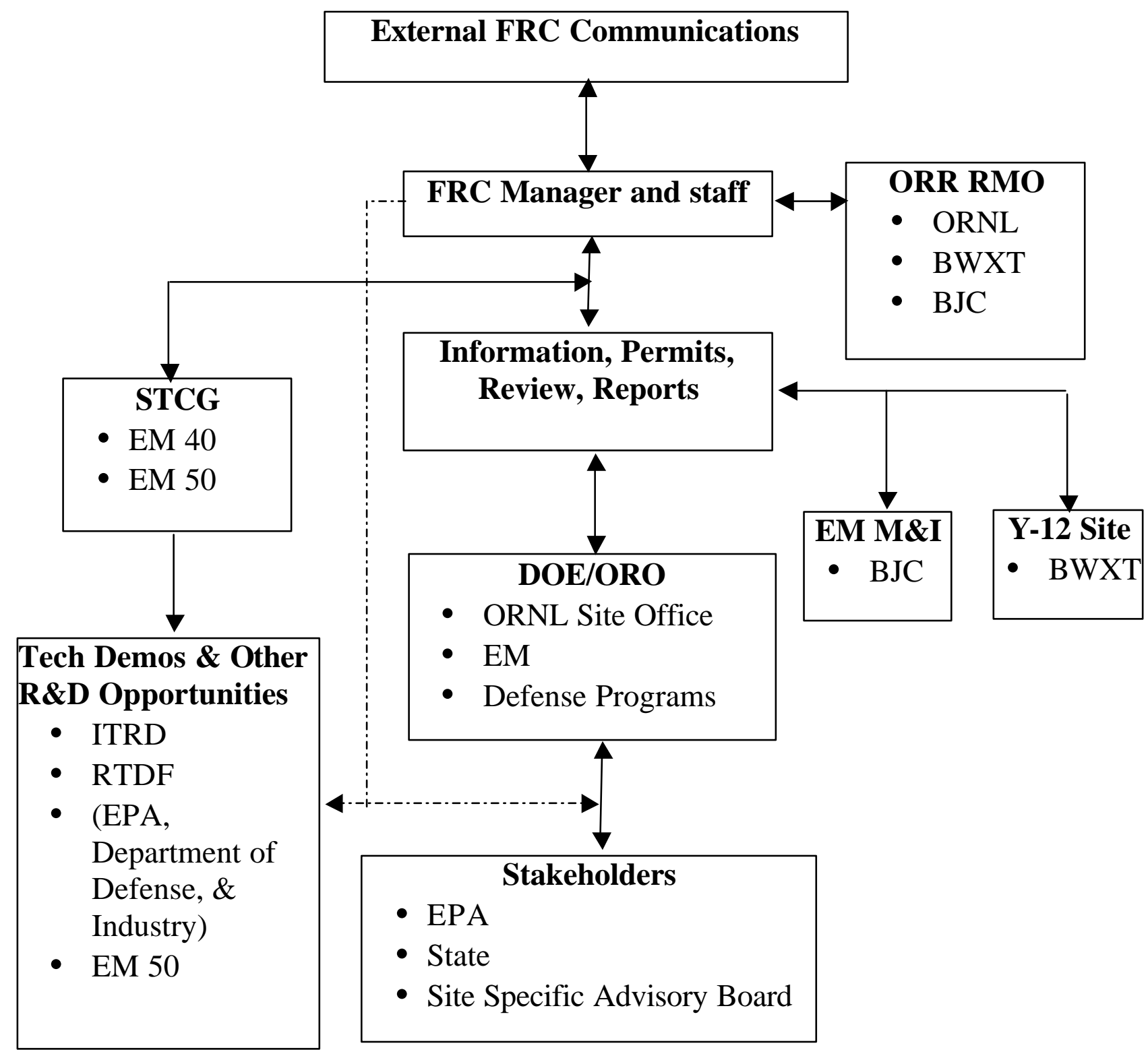

Fig. 4.1 Interaction of FRC staff with other parties. 
The FRC Manager and staff will communicate directly with regulatory compliance staff members at ORNL who have responsibility for permitting of various activities. In addition, the FRC Manager will meet with the CERCLA Federal Facilities Agreement Project Managers as necessary to avoid conflicts with CERCLA activities. These activities are described in detail in Sections 5 and 6.

\subsection{REPORTING REQUIREMENTS}

\subsubsection{FRC Manager}

The FRC Manager provides a series of reports to the NABIR Field Activities Manager during the funding year. These reports include a quarterly general progress report and an annual summary report. All reports are submitted in hard copy and electronic form (e.g., Word, Word Perfect, Excel, etc.) to the contracting officer at the Oak Ridge Operations Office and the NABIR Field Activities Manager. A brief description of these reports and their contents follows:

Quarterly Report - A quarterly report will be submitted December, March, June, and September each year. Contents include quarterly progress on scientific accomplishments, information on additional characterization data obtained, field site operational issues, planned characterization and research campaigns for the next quarter, the status of information disseminated to NABIR investigators, and financial information.

Annual Summary Report - An annual summary report will be submitted in September of each year. It contains a summary of the information provided in the quarterly reports and plans for the following year.

\subsubsection{NABIR Investigator Reports}

NABIR investigators provide quarterly reports to the FRC Manager and periodic reports to DOE Headquarters as specified in project funding documentation. The quarterly report will be submitted December, March, June, and September each year and will include scientific accomplishments, information on additional characterization data obtained, field site operational issues, planned characterization and research campaigns for the next quarter, the status of information disseminated to NABIR investigators, and financial information. This information will be used by the FRC Manager to prepare his quarterly report. 


\section{PROCEDURES FOR NABIR INVESTIGATORS TO INITIATE PROJECTS}

This section outlines the procedures for NABIR investigators to guide them in using the FRC field sites for in situ research (i.e., criteria for making selection and/or prioritization on whether a NABIR investigator(s) can undertake an in situ research investigation). A flow diagram illustrating the entire process from project origination through review and implementation at the FRC is included in Appendix B. The entities responsible for each of the activities comprising this process are shown in Table 5.1.

The NABIR Program Element Managers solicit proposals from potential NABIR investigators for projects that meet the goals and objectives of the NABIR Program and are suitable for implementation at the FRC. Submitted proposals are peer reviewed and successful proposals are selected. These proposals are then submitted to the FRC Manager who reviews each proposal to determine whether there is a high probability that the project can be successfully implemented at the FRC. If not, then the proposal is referred to the NABIR Program Element Managers for additional consideration and possible modification. If the proposed project is appropriate for the conditions at the FRC then the FRC Manager recommends to the NABIR Field Activities Manager that the project be approved for implementation.

Information necessary to implement the project will be obtained from work plans prepared by the NABIR investigator. The process for submittal and review of investigator work plans and providing supplementary information as necessary is described below. For most projects, the review process will take only a few days to complete. However, some projects may take longer if there are special permitting requirements or other complicating factors.

If approved by NABIR, the FRC Manager is notified that the project is to be implemented. He then requests a workplan from the NABIR investigator describing the project's location within the FRC, and the nature and duration of activities to be conducted. The work plan is reviewed for implementability by the FRC Manager and the FRAP staff for completeness; If additional information is required in order to properly evaluate the project, the FRC Manager requests it from the NABIR investigator.

The FRC Manager will use the information provided by the NABIR investigator to determine whether the proposed project is within the scope of a Memorandum of Understanding (MOU) among the Oak Ridge Reservation contractors, and does not conflict with CERCLA activities at the site. In most cases, proposed research is already covered under the existing MOU and is also free of CERCLA conflicts. The work plan is provided for review as needed to DOE Environmental Management at the Oak Ridge Operations, Bechtel Jacobs Company, and BWXT Y-12. The scope of the review performed by Bechtel Jacobs Company and BWXT Y-12 is governed by the MOU among these parties and Oak Ridge National Laboratory. The MOU specifies, among other things, whose operating and waste certification procedures are used (where and when), and who maintains specific areas.

Based on the work plan, the project is reviewed to determine if there are any potential conflicts with planned CERCLA activities. If the project is to be conducted in a contaminated area of the Bear Creek Valley, then DOE Environmental Management determines if the proposed work presents any potential conflict with CERCLA remediation or monitoring. If not, then the review is completed. If there is a potential conflict, then Environmental Management informs the FRC Manager, EPA, and TDEC. The FRC Manager attempts to resolve the conflict by working with the NABIR investigator to change the project timing, location, and potentially the scope. If more information is requested by the EPA or TDEC, it is provided. If these efforts do not resolve the conflict, then the FRC Manager presents project details at a Federal Facility Agreement Project Managers meeting for evaluation by the parties. The Federal Facility Agreement Project Managers 
then determine if unresolved concerns remain. If so, the project is suspended until the conflict issues are resolved. If the resolution requires significant changes that could impact the technical aspects of the project, then the revised work plan may be resubmitted to the FRAP for review.

If there are no CERCLA conflicts, or when any such potential conflicts are resolved, the proposed project is evaluated to determine if the activities are within the MOU with respect to Bechtel Jacobs Company. The FRC Manager and/or Bechtel Jacobs Company make this determination. If the project is not within the scope of the MOU, the FRC Manager and Bechtel Jacobs Company will modify the MOU as necessary.

If the project is within the MOU with respect to Bechtel Jacobs Company, it will be further evaluated to determine if the activities are within the MOU with respect to BWXT Y-12; The FRC Manager and BWXT Y12 make this determination. If the project is not within the scope of the MOU, the FRC Manager and BWXT Y-12 will modify the MOU as necessary.

After a potential project is determined to be free of CERCLA conflicts and within the Working Agreements with Bechtel Jacobs Company and BWXT Y-12, a review of the proposed project activities can begin to determine ESH\&Q requirements as described in Sect. 6.0. In some cases, these processes are conducted concurrently.

Limited ad-hoc field activities such as limited collection of cores and groundwater samples can be approved by the FRC Manager with prior concurrence from the NABIR Field Activities Manager. All proposed field activities for this type of work are documented, evaluated, and approved prior to initiation of any on-site activity. However, any activity that has potential to impact on-going studies, regulatory limitations, and FRC resources will generally be evaluated by the FRAP. 
Table 5.1. Entities responsible for activities in the FRC Project organization, review, and implementation process

\begin{tabular}{|c|c|c|c|c|c|c|c|c|c|c|}
\hline Activity & DOE HQ & DOE ORO & FRAP & $\begin{array}{l}\text { ORNL FRC } \\
\text { MGR/Staff }\end{array}$ & $\begin{array}{l}\text { ORNL } \\
\text { Compliance } \\
\text { Staff } \\
\end{array}$ & $\begin{array}{l}\text { ORNL } \\
\text { Administrati } \\
\text { ve Staff }\end{array}$ & NABIR Inv. & BJC & BWXT & $\begin{array}{l}\text { Other } \\
\text { Institutions }\end{array}$ \\
\hline Proposal solicited & $\mathbf{X}$ & & & & & & & & & \\
\hline Proposal submitted & & & & & & & $\mathbf{x}$ & & & \\
\hline Peer review & $\mathbf{X}$ & & & & & & & & & $\mathbf{X}$ \\
\hline Successful proposals selected & $\mathbf{X}$ & & & & & & & & & \\
\hline Review for FRC suitability & & & $\mathbf{X}$ & $\mathbf{X}$ & & & & & & \\
\hline Approval for implementation & $\mathbf{X}$ & & & & & & & & & \\
\hline $\begin{array}{l}\text { Work plan requested from NABIR } \\
\text { investigator }\end{array}$ & & & & $\mathbf{X}$ & & & & & & \\
\hline Work plan prepared and submitted & & & & & & & $\mathbf{X}$ & & & \\
\hline Work plan reviewed for implementability & & & & $\mathbf{X}$ & $\mathbf{X}$ & & & & & \\
\hline $\begin{array}{l}\text { Work plan provided to ORO, BJC, \& } \\
\text { BWXT }\end{array}$ & & & & $\mathbf{X}$ & & & & & & \\
\hline CERCLA Program review & & $\mathbf{x}$ & & $\mathbf{X}$ & & & $\begin{array}{c}\mathbf{X} \\
\begin{array}{c}\text { Potential } \\
\text { involvement }\end{array} \\
\end{array}$ & $\mathbf{x}$ & & $\begin{array}{c}\mathbf{X} \\
\text { EPA, TDEC }\end{array}$ \\
\hline BJC Working Agreement review & & & & $\mathbf{x}$ & & & & $\begin{array}{c}\mathbf{X} \\
\begin{array}{c}\text { Potential } \\
\text { involvement }\end{array} \\
\end{array}$ & & \\
\hline LMES Working Agreement review & & & & $\mathbf{X}$ & & & & & $\begin{array}{c}\mathrm{X} \\
\begin{array}{c}\text { Potential } \\
\text { involvement }\end{array}\end{array}$ & \\
\hline $\begin{array}{l}\text { Complete ESD Project Review/NEPA } \\
\text { Checklist }\end{array}$ & & & & $\mathbf{X}$ & $\bar{X}$ & & $\mathbf{X}$ & & & \\
\hline ISMS Review & & & & $\mathbf{X}$ & & & & & & \\
\hline Requirements list compiled & & & & $\mathbf{X}$ & $\mathbf{X}$ & & & & & \\
\hline $\begin{array}{l}\text { NABIR investigator signs agreement to } \\
\text { comply with requirements-project } \\
\text { approved }\end{array}$ & & & & $\mathbf{X}$ & & & $\mathbf{X}$ & & & \\
\hline $\begin{array}{l}\text { NABIR investigator and FRC Manager agree } \\
\text { on division of tasks and responsibilities }\end{array}$ & & & & $\mathbf{X}$ & & & $\mathbf{X}$ & & & \\
\hline Notification of DOE, BJC, BWXT & & & & $\mathbf{X}$ & & & & & & \\
\hline $\begin{array}{l}\text { Site clearance obtained for NABIR } \\
\text { investigator through Non-Employee } \\
\text { Processing }\end{array}$ & & & & $\mathbf{X}$ & & $\begin{array}{c}X \\
\text { NEP office }\end{array}$ & $\mathbf{X}$ & & & \\
\hline $\begin{array}{l}\text { Training review and training of PI as } \\
\text { necessary }\end{array}$ & & & & $\mathbf{X}$ & $\mathbf{x}$ & $\mathbf{x}$ & $\mathbf{x}$ & & & $\begin{array}{c}X \\
\text { If trained } \\
\text { elsewhere }\end{array}$ \\
\hline $\begin{array}{l}\text { Administrative and housekeeping } \\
\text { arrangements completed for NABIR } \\
\text { investigator }\end{array}$ & & & & $\mathbf{X}$ & & & & & & \\
\hline Project is performed & & & $\begin{array}{c}\mathbf{X} \\
\text { Provides } \\
\text { Input }\end{array}$ & $\mathbf{x}$ & & & $\mathbf{x}$ & $\begin{array}{c}X \\
\text { Provides } \\
\text { Waste Mgnt } \\
\text { Services } \\
\end{array}$ & & \\
\hline Compliance is assured & $\mathbf{X}$ & $\mathbf{X}$ & $\mathbf{X}$ & $\mathbf{X}$ & $\mathbf{X}$ & & $\mathbf{X}$ & & & \\
\hline $\begin{array}{l}\text { Project monitored per ISMS; modifications } \\
\text { made as necessary }\end{array}$ & & & & $\mathbf{x}$ & $\mathbf{x}$ & & $\mathbf{x}$ & & & \\
\hline Periodic reporting to DOE & & & & $\mathbf{X}$ & & & $\mathbf{X}$ & & & \\
\hline Project closeout & & $\mathbf{X}$ & & $\mathbf{X}$ & $\mathbf{X}$ & $\mathbf{X}$ & $\mathbf{X}$ & & & \\
\hline
\end{tabular}




\section{SITE-SPECIFIC PROJECT REQUIREMENTS REVIEW}

The FRC Manager and NABIR investigators are responsible for ensuring ESH\&Q compliance at all stages of each project and the sample handling life cycle. The Oak Ridge National Laboratory ISMS program is employed as the framework and overall approach to meeting all ESH\&Q requirements. A major principle of ISMS is the identification of standards and requirements before work is performed. Oak Ridge National Laboratory has in place various compliance-related organizations which are responsible for identifying the entire spectrum of requirements that could apply to a particular project. These requirements arise from federal and state statutes and regulations, executive orders, DOE orders, work smart standards, and compliance and settlement agreements. For particular projects or classes of activities, Oak Ridge National Laboratory evaluates the associated hazards (to human health and the environment) and establishes an agreedupon set of working standards and requirements, which, when properly implemented, provide adequate assurance that workers, the public, and the environment are protected from adverse consequences.

The ISMS program is implemented at the FRC as described below and shown in the FRC process flow diagram included as Appendix B. For each proposed project, FRC staff, in consultation with NABIR investigators, will prepare an Oak Ridge National Laboratory Environmental Sciences Division ESH\&Q Project Evaluation checklist (Appendix C). This checklist contains specific questions keyed to Oak Ridge National Laboratory procedures and associated requirements. Hard copies of all procedures, requirements, and other documents and plans related to the FRC are kept in an on-site library at Oak Ridge National Laboratory. The ESH\&Q Project Evaluation checklist is completed by FRC staff based on information contained in the NABIR investigator's work plan. The checklist is then reviewed by representatives within the following Oak Ridge National Laboratory compliance-related organizations: Environmental Protection (includes National Environmental Policy Act Compliance), Training, Radiation Control, Industrial Hygiene, Laboratory Waste Services, Quality Assurance, and the Resource Management Organization. These representatives request additional information from the FRC Manager to the extent necessary to aid them in identifying all applicable regulatory and other requirements that would apply during the project and sample handling life cycle. These requirements, including the need for any new permits or modifications to existing permits, are then listed in a document prepared by FRC staff. Operation of the FRC has been addressed in an Environmental Assessment (DOE 2000a) and subsequent Finding of No Significant Impact (DOE 2000b) prepared pursuant to the National Environmental Quality Act. Approval of projects is granted subject to the NABIR investigators' written agreement to meet all identified requirements. The FRC Manager and NABIR investigators bear responsibility for assuring that NABIR investigators comply with ESH\&Q requirements. If project NABIR investigators do not follow ESH\&Q procedures, they will not be allowed to work on site. Worker safety is of the greatest concern to DOE and the FRC Manager and staff.

As experience is gained, new plans submitted by NABIR investigators for sampling or research with recurring classes of similar activities will be reviewed by the FRC Manager to determine whether they fall within the boundaries of previously approved activities and procedures. If so, the established requirements will be followed, as documented in an agreement signed by the NABIR investigator, and further review will not be necessary. A memo to FRC records and the Environmental Sciences Division ESH\&Q Coordinator will document this process. 


\subsection{PERMITS}

Following identification of the requirements for a particular FRC project, the process for obtaining the necessary permits or permit modifications can begin. In some cases, the processes can be conducted concurrently. Oak Ridge National Laboratory has a good record of working with regulators to gain rapid approval for activities similar to those that might be conducted at the FRC. To the extent feasible, permits are obtained for classes of similar activities to lessen the need for acquiring or modifying permits on a projectspecific basis. Similarly, as internal and external requirements are identified (e.g., sample transportation shipping and safety requirements), methods are developed to rapidly process various classes of similar samples to assure their timely analysis while minimizing the procedural burden on NABIR investigators.

\subsection{TRAINING REQUIREMENTS}

Work conducted at the contaminated area of the FRC may fall under the scope of 29 CFR 1910.120, Hazardous Waste Operations and Emergency Response (HAZWOPER). Related requirements that are applicable to each NABIR investigator and staff member are those regulating access to the FRC site and associated buildings. All personnel requiring long-term access (more than 10 days in one year) to the site must successfully complete General Employee Training. This training is required by DOE Orders 5480.10 and 5480.40, and the Occupational Safety and Health Act of 29 CFR 1910.1200, and 1910.1450. The purpose of General Employee Training is to provide an overview of hazards present at the site; the means used to identify hazardous areas; site emergency procedures and alarms; site safety and quality assurance programs; and site policies, procedures, and instructions that apply to all employees. All personnel requiring unescorted short-term access (less than 10 days in one year) must review the Visitor Guide for Oak Ridge National Laboratory. In addition, laboratory personnel are required to have Hazard Communication training and job specific training (e.g., Fume Hood Training, Radiation Worker II). Both laboratory and field personnel are required to complete project-specific training that may include procedures for tracer injection, sampling, and analysis and for obtaining and recording field measurements. Personnel working at the contaminated site require 24-hr HAZWOPER training at a minimum. Personnel involved with core extraction near the S-3 ponds or requiring entry to designated Radiological Areas will also require Radiation Worker II training. Laboratory-specific training provided by the Laboratory Steward is required to work in the Environmental Sciences Division laboratories. All required training is available through Oak Ridge National Laboratory in addition to a variety of other institutions.

Project requirements must be consistent with the FRC Site-Specific Health and Safety Plan (HASP). The purpose of the FRC Site-Specific HASP is to establish health and safety guidelines to be followed by all personnel performing work at the FRC. Work is conducted in accordance with requirements identified in the Oak Ridge National Laboratory HAZWOPER Program Manual and applicable DOE and Oak Ridge National Laboratory policies and procedures. The Site-Specific HASP serves as an extension of the Oak Ridge National Laboratory HAZWOPER Program Manual. The combined plans fulfill the requirements of 29 CFR 1910.120.

\subsection{TRANSPORTATION REQUIREMENTS}

Applicable Department of Transportation (DOT) requirements for the packaging and shipping of samples are identified by the Oak Ridge National Laboratory Transportation Specialist. A specific Sample Transportation Checklist is completed by FRC staff during the ISMS review for all projects involving transport of samples on 
public roads. The checklist includes questions about the specific activity of the material, its flashpoint, whether or not it is preserved, if samples contain hazardous materials, if the sample is a Resource Conservation and Recovery Act waste, and whether there is any question about the hazardous nature or radioactivity of the shipment. Based on past experience with sample collection in the Bear Creek Valley, samples collected at the FRC are generally below both the DOT radioactivity limit of $70 \mathrm{~Bq} / \mathrm{g}$, and the limits for transportation of corrosives/preservatives. However, the potential to exceed DOT regulations does exist. Therefore, special provisions for sample transportation are required if DOT regulations are exceeded. Off-site laboratories receiving samples are required to document that they have obtained the necessary approvals from the governing regulatory agency to handle anticipated radioactivity and other contaminant levels. Chain-ofcustody and sample receipt notification is maintained by the FRC Manager as specified in the FRC Data Management Plan.

\subsection{EMERGENCY RESPONSE}

The Y-12 National Security Complex emergency response organization is located in close proximity to the FRC and will be contacted for response to all emergencies at the FRC. The Plant Shift Superintendent will coordinate all emergency response operations and can be reached by dialing 911 from any plant telephone or by calling (865) 574-7172 for emergency medical assistance and first aid. Medical assistance will be provided by either the Y-12 Health Division doctor and/or nurse, or Y-12 Protective Services Organization Emergency Medical Technicians. 


\section{POLICY FOR NON-OAK RIDGE NATIONAL LABORATORY EMPLOYEES}

Oak Ridge National Laboratory policy, for the FRC as well as all other laboratory operations, requires that use of laboratory resources (e.g., analytical facilities, etc.), DOE site equipment (e.g., drilling equipment, vehicles, etc.), and sample storage operations be conducted in accordance with the requirements of all federal and state statutes and regulations, executive orders, DOE orders, work smart standards, compliance and settlement agreements, and NABIR work plans. Compliance with this policy is implemented primarily through the review process as explained in Sect. 6.0.

Because many NABIR investigators will not be employees of Oak Ridge National Laboratory, there are additional considerations and requirements associated with the use of Oak Ridge National Laboratory facilities by those who are not bound by the requirements and understandings specific to the employer-employee relationship. Although many such requirements are determined through the ISMS process, an additional specific review is conducted through the Non-Employee Processing procedure.

After tentatively approving projects that have completed the ISMS review, the FRC Manager initiates the NonEmployee Processing procedure. During this review, information concerning the project, NABIR investigators, and all non-Oak Ridge National Laboratory employees including U.S. Citizens and foreign nationals, is reviewed by appropriate Environmental Sciences Division and Non-Employee Processing contacts, and any additional requirements for non-employees, including all ESH\&Q training requirements, are identified. Note: the processing procedure for foreign nationals can take up to several months, and plans should be made accordingly. NABIR investigators are notified of these requirements by the FRC Manager and may then report to Oak Ridge National Laboratory for entry badging. If non-employees have not completed the required training at this time, they may complete it at Oak Ridge National Laboratory before work on the project begins.

Once project requirements are defined, the NABIR investigator and FRC Manager will come to an agreement on how project task responsibilities will be divided (e.g., who will conduct specific sampling analysis and well installations). The task responsibilities will be documented and signed by the NABIR investigator and FRC Manager, and placed in the FRC files. 


\section{SAMPLE STORAGE AND DATA MANAGEMENT}

Samples to be stored and archived will be managed in compliance with 10 CFR Part 835 which establishes radiation protection standards, limits, and program requirements for protecting individuals from ionizing radiation resulting from the conduct of DOE activities. Storage areas will be posted and monitored as necessary consistent with these requirements as identified in the ISMS. Archived samples are stored in an $80^{\circ} \mathrm{C}$ freezer as needed. Sample chain-of-custody will be maintained by the FRC Manager.

As part of Oak Ridge National Laboratory's environmental restoration work, procedures for submitting large volumes of electronic data to a centralized data repository were developed (North et al., 1997). This experience forms the foundation for the Data Management System, which is described in the FRC Quality Assurance Plan.

NABIR investigators are expected to provide the FRC Manager with any data collected at the FRC in a format suitable for loading into the FRC Data Management System. 


\section{PROCEDURES FOR WASTE DISPOSAL}

Project-related wastes generated at the contaminated field site which require disposal will be treated and disposed of, as appropriate, by Bechtel Jacobs Company. BWXT Y-12 may be contacted by FRC staff to assist in the handling, storage, classification, and delivery of wastes to Bechtel Jacobs Company. For most projects, wastes will be stored in drums or other suitable containers for ultimate disposal by Bechtel Jacobs Company. All associated requirements will be determined through the ISMS review process (Sect. 6.0). Existing Bechtel Jacobs Company waste certification procedures will be employed. Once project waste is placed in the custody of Bechtel Jacobs Company, no further costs associated with its handling and ultimate disposal will be borne by the FRC. A Satellite Accumulation Area for Resource Conversation and Recovery Act waste generated from field analysis using Hach kits has been established at the S-3 Ponds Area 1 site. Dumpsters for disposal of uncontaminated wastes and personal protective equipment wastes (e.g., disposable gloves and tyvek) will also be available at the FRC contaminated field site. 


\section{CONFLICT OF INTEREST AND INTELLECTUAL PROPERTY RIGHTS}

The approach to handling conflict of interest issues as well as intellectual property rights of all parties, including ownership of both microorganisms and experimental data obtained from the FRC field sites, is determined through the Oak Ridge National Laboratory directives and guidance on technology transfer. These include Directives ORNL-TT-001 through ORNL-TT-007, and Guidance document ORNL-TT-G1 (http://www-internal.ornl.gov/ORNL/directives/tt.htm).

DOE's Assistant General Counsel for Technology Transfer and Intellectual Property addressed some of these issues in a guidance letter entitled Bailment of Biological Materials and Tangible Research Products, that was sent to DOE Field Office Patent Counsels on September 3, 1998. The NABIR Program is assisting with development of further guidance documentation as needed. 


\section{CHARACTERIZATION AND RESEARCH CAMPAIGN ACTIVITIES AND PLANS}

A separate Site Characterization Plan addresses the scope and initial characterization of the FRC. Characterization activities are expected to begin in September 2000 and conclude by the end of the calendar year. Thus, cores, groundwater, and other environmental samples can be made available to NABIR investigators as these activities get underway. Results of the characterization investigations will be presented at the annual NABIR investigators meeting in Washington, D.C., in January 2001. Detailed characterization efforts by investigators for research projects are addressed individually through the processes described in this Management Plan. 


\section{PROJECTED SCHEDULE OF ACTIVITIES}

- Finalization of FRC Management Plan - September, 2000

- Initiation of site characterization field work - September, 2000

- Funding to selected NABIR Investigators - late September, 2000

- Completion of site characterization field work - late December, 2000

- Initiation of field work for projects - December, 2000

- Full-scale field work in progress - September 2001 


\section{SITE CLOSURE PLAN}

At the cessation of FRC research activities all FRC supplies, equipment, field trailers, and wells and associated structures will be distributed among ORNL, Bechtel Jacobs Company, and BWXT Y-12 as appropriate. Supplies and equipment owned by UT-Battelle will be removed from FRC sites unless they are transferred to BWXT Y-12 and/or Bechtel Jacobs Company. Supplies and equipment owned by BWXT Y-12 and Bechtel Jacobs Company (if any) shall be returned to them. FRC field trailers will either be removed and site services terminated, or turned over to BWXT Y-12 or Bechtel Jacobs Company. FRC wells and associated structures installed by the FRC at the FRC contaminated field site will be plugged and abandoned unless BWXT or Bechtel Jacobs Company agrees to accept them. FRC wells and associated structures installed by the FRC at the FRC background area will be either left in place for future use, or turned over to BWXT if requested. 


\section{REFERENCES}

Department of Energy (DOE). 1995. Natural and Accelerated Bioremediation Research NABIR Program Plan. Office of Energy Research, Office of Health and Environmental Research, DOE/ER-0659T UC 402, September.

Department of Energy (DOE). 1999a. Letter Request for Field Research Center (FRC) Proposals and Applicant's Environmental Analysis for the Natural and Accelerated Bioremediation Research Program. Office of Biological and Environmental Research, Office of Science.

Department of Energy (DOE). 1999b. Preferred Characteristics for the Proposed Field Research Center Field Site. Office of Science, Office of Biological and Environmental Research, Environmental Sciences Division. January.

Department of Energy (DOE). 1999c. Management and Operational Expectations for the Proposed Field Research Centers for the Natural and Accelerated Bioremediation Research Program. Office of Science, Office of Biological and Environmental Research, Environmental Sciences Division. January.

Department of Energy (DOE). 2000a. Environmental Assessment for Selection and Operation of the Proposed Field Research Centers for the Natural and Accelerated Bioremediation Research (NABIR) Program. Office of Science, Office of Biological and Environmental Research. DOE/EA-1196. March 7.

Department of Energy (DOE). 2000b. Find of No Significant Impact - Selection and Operation of the Proposed Field Research Centers for the Natural and Accelerated Bioremediation Research (NABIR) Program. Office of Science, Office of Biological and Environmental Research. DOE/EA-1196. April 8.

Gibson, D.T., and Sayler, G.S. 1992. Scientific Foundations of Bioremediation: Current Status and Future Needs. American Academy of Microbiology, Washington, D.C.

North, M.P., C.C. Brandt, S.W. Christensen, J.B. Atwater, and D.S. Tharpe. 1997. Technical specification for transferring biota data to the Oak Ridge Environmental Information System (OREIS). ES/ER/TM-195. Lockheed-Martin Energy Systems, Oak Ridge, TN.

Oak Ridge National Laboratory. 1993. ORNL HAZWOPER Program Manual. ORNL/M-2716. March 17. 
Appendix A

CONTACT LIST OF INDIVIDUALS AND ORGANIZATIONS

IMPORTANT TO THE OPERATION OF THE FRC 



\section{BECHTEL JACOBS COMPANY}

$\begin{array}{ll}\text { Name: } & \text { Ed Trujillo } \\ \text { Organizational Unit: } & \text { Project Management } \\ \text { Title or FRC Role: } & \text { CERCLA Watershed Manager } \\ \text { E-mail: } & \text { trujilloe@ @echtel.jacobs.org } \\ \text { Phone: } & 865.241 .6728 \\ \text { Fax: } & 865.576 .6339 \\ \text { Building: } & 1007 \\ \text { Room: } & 2201 \\ \text { Mail Stop: } & 7053 \\ \text { Address: } & \text { Bechtel Jacobs Company LCC } \\ & \text { P.O. Box 4699 } \\ & \text { Oak Ridge, TN 37831-7053 } \\ \text { Name: } & \text { Janice F. Hensley } \\ \text { Organizational Unit: } & \text { Engineering } \\ \text { Title or FRC Role: } & \text { CERCLA Project Manager } \\ \text { E-mail: } & \text { hensleyjf@ bechtel.jacobs.org } \\ \text { Phone: } & 865.574 .2930 \\ \text { Fax: } & 865.576 .6339 \\ \text { Building: } & 1007 \\ \text { Room: } & 2201 \\ \text { Mail Stop: } & 7053 \\ \text { Address: } & \text { Bechtel Jacobs Company LCC } \\ & \text { P.O. Box 4699 } \\ & \text { Oak Ridge, TN 37831-7053 }\end{array}$

\section{DOE HEADQUARTERS}

\section{Name:}

Organizational Unit: Title or FRC Role:

E-mail:

Phone:

Fax:

Building:

Room:

Mail Stop:

Address:

\section{Paul E. Bayer}

Office of Science (SC-74)

NABIR Field Activities Manager

paul.bayer@science.doe.gov

301.903.5324

301.903 .8519

GTN

G-137

F-240

U.S. Department of Energy Headquarters 19901 Germantown Road

Germantown, MD 20874-1290 
Name:

Organizational Unit:

Title or FRC Role:

E-mail:

Phone:

Fax:

Mail Stop:

Address:

\section{Name:}

Organizational Unit:

Title or FRC Role:

E-mail:

Phone:

Fax:

Building:

Address:

\section{Name:}

Organizational Unit:

Title or FRC Role:

E-mail:

Phone:

Fax:

Building:

Room:

Mail Stop:

Address:
Room:

Terry C. Hazen

NABIR Program Support Office

FRAP (Field Research Advisory Panel) Coordinator

TCHazen@lbl.gov

510.486 .6223

510.486 .7152

70A-3317

Lawrence Berkeley National Laboratory

1 Cyclotron Road

Berkeley, CA 94720

Clarence R. Hickey

Office of Science (SC-83)

NEPA Compliance Officer

clarence.hickey@science.doe.gov

301.903.2314

none given

GTN

F-436

U.S. Department of Energy Headquarters 19901 Germantown Road

Germantown, MD 20874-1290

John C. Houghton

Office of Science (SC-74)

NABIR Program Coordinator

john.houghton@science.doe.gov

301.903.8288

301.903 .8519

GTN

G-136

F-240

U.S. Department of Energy Headquarters

19901 Germantown Road

Germantown, MD 20874-1290

Name:
Organizational Unit:
Title or FRC Role:
E-mail:
Phone:
Fax:
Building:
Room:
Mail Stop:
Address:

Anna Palmisano

Office of Science (SC-74)

NABIR Program Coordinator

anna.palmisano@science.doe.gov

301.903 .9963

301.903 .8519

GTN

G-155

F-240

U.S. Department of Energy Headquarters 19901 Germantown Road

Germantown, MD 20874-1290 
DOE OAK RIDGE OPERATIONS OFFICE

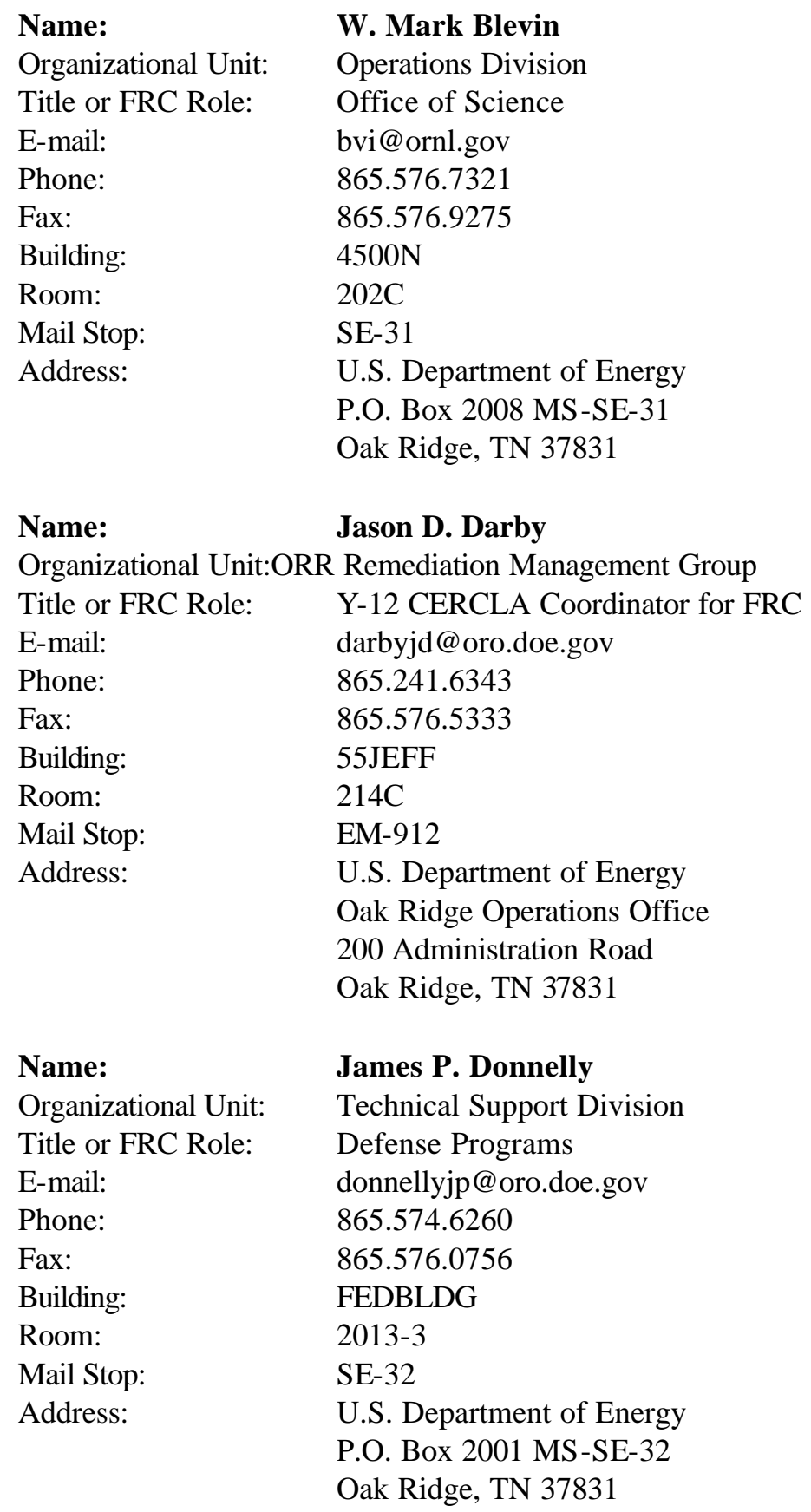


Name:

Organizational Unit: Title or FRC Role:

E-mail:

Phone:

Fax:

Building:

Room:

Mail Stop:

Address:

\section{Myrna Redfield}

ORR Remediation Management Group

FFA Coordinator

redfieldme@ oro.doe.gov

865.576.8528

865.576 .3799

$55 \mathrm{JEFF}$

$209 \mathrm{~K}$

EM-91

U.S. Department of Energy

Oak Ridge Operations Office

200 Administration Road

Oak Ridge, TN 37831

\section{Name:}

Organizational Unit: Title or FRC Role:

E-mail:

Phone:

Fax:

Building:

Room:

Mail Stop:

Address:

\section{Sylvia J. Wolfe}

ORNL Site Office

Oak Ridge Operations Office FRC Coordinator

wolfe@ornl.gov

865.576 .4065

865.574 .9275

$4500 \mathrm{~N}$

$216 \mathrm{~A}$

6269

Oak Ridge National Laboratory

P.O. Box 2008 MS 6269

Oak Ridge, TN 37831-6269

\section{ORNL - UT-BATTELLE}

\section{Name:}

Organizational Unit:

Title or FRC Role:

E-mail:

Phone:

Fax:

Building:

Room:

Mail Stop:

Address:

\section{Mary Anna Bogle}

Environmental Sciences Division

Site Safety and Health Officer, Team Leader, Field Technician Boglema@ornl.gov

865.574.7824

865.574 .8543

1505

208

6036

Oak Ridge National Laboratory

P.O. Box 2008

Oak Ridge, TN 37831-6036 


\section{Name:}

Organizational Unit:

Title or FRC Role:

E-mail:

Phone:

Fax:

Building:

Room:

Mail Stop:

Address:
Craig C. Brandt

Environmental Sciences Division

Data Manager

brandtcc@ornl.gov

865.574.1921

865.576 .8646

1505

330

6038

Oak Ridge National Laboratory

P.O. Box 2008

Oak Ridge, TN 37831-6038

Steve E. Childs

Environmental Protection and Waste Services Division

Generator Interface/Waste Handling Coordinator

childss@ornl.gov

865.241 .2807

865.576 .0105

3047

$228 \mathrm{c}$

6023

Oak Ridge National Laboratory

P.O. Box 2008

Oak Ridge, TN 37831-6038

\section{Name:}

Phone:

Address:

Name:

Organizational Unit: Title or FRC Role:

E-mail:

Phone:

Fax:

Building:

Room:

Mail Stop:

Address:

\section{Emergency Services for ORNL}

911 from any ORNL telephone

Or 865.574.6606 from an outside telephone for Laboratory Shift Superintendent

Oak Ridge National Laboratory

P.O. Box 2008

Oak Ridge, TN 37831-6343

\section{Norman Farrow}

Environmental Sciences Division

Principal Field Technologist

Farrownd@ornl.gov

865.574.7419

865.576 .9939

1506

$116 \mathrm{~A}$

6034

Oak Ridge National Laboratory

P.O. Box 2008

Oak Ridge, TN 37831-6034 
Name:

Organizational Unit: Title or FRC Role:

E-mail:

Phone:

Fax:

Building:

Room:

Mail Stop:

Address:
Susan K. Holladay

Environmental Sciences Division

Field Technologist

holladaysk@ornl.gov

865.576.8356

865.576 .8646

1506

366

6036

Oak Ridge National Laboratory

P.O. Box 2008

Oak Ridge, TN 37831-6036

\section{Name:}

Organizational Unit:

Title or FRC Role:

E-mail:

Phone:

Fax:

Building:

Room:

Mail Stop:

Address:

\section{George F. Houser}

ESH\&Q Directorate

Radiation Surveillance Specialist

housergf@ornl.gov

865.576.1408

865.241 .2779

1505

169

6035

Oak Ridge National Laboratory
P.O. Box 2008

Oak Ridge, TN 37831-6035

\section{Laboratory Shift Superintendent}

ORNL

865.574.6606

or 911 from any ORNL telephone for Emergency Services

4512

105

6343

Oak Ridge National Laboratory

P.O. Box 2008

Oak Ridge, TN 37831-6343

\section{Name:}

Organizational Unit:

Title or FRC Role:

E-mail:

Phone:

Fax:

Building:

Room:

Mail Stop:

Address:

\section{Patricia D. Parr}

Environmental Sciences Division

ORNL RMO Coordinator

parrpd@ornl.gov

865.576.8123

865.576 .8646

1505

$305 \mathrm{~A}$

6038

Oak Ridge National Laboratory

P.O. Box 2008

Oak Ridge, TN 37831-6038 
Name:

Organizational Unit: Title or FRC Role:

E-mail:

Phone:

Fax:

Building:

Room:

Mail Stop:

Address:

\section{Harry D. Quarles}

Environmental Sciences Division Regulatory Specialist quarleshdiii@ornl.gov 865.241.2412

865.576 .8543

1505

202

6036

Oak Ridge National Laboratory

P.O. Box 2008

Oak Ridge, TN 37831-6036

\section{Lynda Campbell}

Environmental Sciences Division Project Assistant

campbell1@ornl.gov

865.574.7313

865.576 .8646

1505

392

6038

Oak Ridge National Laboratory

P.O. Box 2008

Oak Ridge, TN 37831-6038

\section{Monty Ross}

Environmental Sciences Division

ESH\&Q Specialist

rossbm@ornl.gov

865.574.7837

865.574 .4946

1505

101

6035

Oak Ridge National Laboratory

P.O. Box 2008

Oak Ridge, TN 37831-6035 
Name:

Organizational Unit: Title or FRC Role:

E-mail:

Phone:

Fax:

Building:

Room:

Mail Stop:

Address:

\section{David B. Watson}

Environmental Sciences Division

FRC Manager

watsondb@ornl.gov

865.241.4749

865.574 .7420

1505

302

6038

Oak Ridge National Laboratory

P.O. Box 2008

Oak Ridge, TN 37831-6038

\section{STAKEHOLDERS}

Name:

Organizational Unit: Title or FRC Role: Phone:

Fax:

Address:

\author{
Amy K. Wolfe \\ Energy Division \\ Communications Specialist - NABIR BASIC Program \\ wolfeak@ ornl.gov \\ 865.574.5944 \\ 865.574 .8884 \\ $4500 \mathrm{~N}$ \\ G14 \\ 6205 \\ Oak Ridge National Laboratory \\ P.O. Box 2008 \\ Oak Ridge, TN 37831-6295
}


Name:

Organizational Unit: Title or FRC Role:

E-mail:

Phone:

Fax:

Building:

Address:

\section{Name:}

Organizational Unit: Title or FRC Role:

Phone:

Fax:

Address:

\section{Name:}

Organizational Unit: Title or FRC Role:

E-mail:

Phone:

Fax:

Address:

\section{Sheree Black}

Site Specific Advisory Board Support Office

SSAB Contact

blacks1@bechteljacobs.org

865.241.3665

$865.576 .5333 \mathrm{y}$

$55 \mathrm{JEFF}$

P.O. Box 2001-E90

Oak Ridge, TN 37831

\section{Doug McCoy}

Tennessee Department of Environment and Conservation (TDEC)

FFA Project Manager

865.481 .0995

865.482 .1835

761 Emory Valley Road

Oak Ridge, TN 37830-7072

\section{Norman A. Mulvenon}

Local Oversight Committee

Citizens Advisory Panel Chair

mulvenon@juno.com

865.482 .3153

865.483 .9234

118 Concord Road

Oak Ridge, TN 37830-7126

\section{Y-12 - BWXT Y-12}

Name:

Phone:

Address:

\section{Emergency Services for Y-12}

911 from a Y-12 Plant telephone BWXT Y-12

P.O. Box 2009

Oak Ridge, TN 37831 
Name:

Organizational Unit: Title or FRC Role:

E-mail:

Phone:

Fax:

Mail Stop:

Address:

Name:

Organizational Unit: Title or FRC Role:

E-mail:

Phone:

Fax:

Building:

Room:

Mail Stop:

Address:

Name:

Phone:

Address:

\section{Cindy F. Hartsell}

Site Services

Waste Management Interface

hartsellcf@y12.doe.gov

865.241.2117

865.241 .5775

8060

BWXT Y-12

P.O. Box 2009

Oak Ridge, TN 37831-8060

James D. Peebles

Site Management

Y-12 Site Services Manager and Y-12 RMO Coordinator peeblesjd@y12.doe.gov

865.576.5572

865.576 .8363

9766

$038 \mathrm{C}$

8114

BWXT Y-12

P.O. Box 2009

Oak Ridge, TN 37831-8114

\section{Plant Shift Superintendent}

865.574.7172

BWXT Y-12

P.O. Box 2009

Oak Ridge, TN 37831 
Appendix B

FRC PROCESS FLOW DIAGRAM 



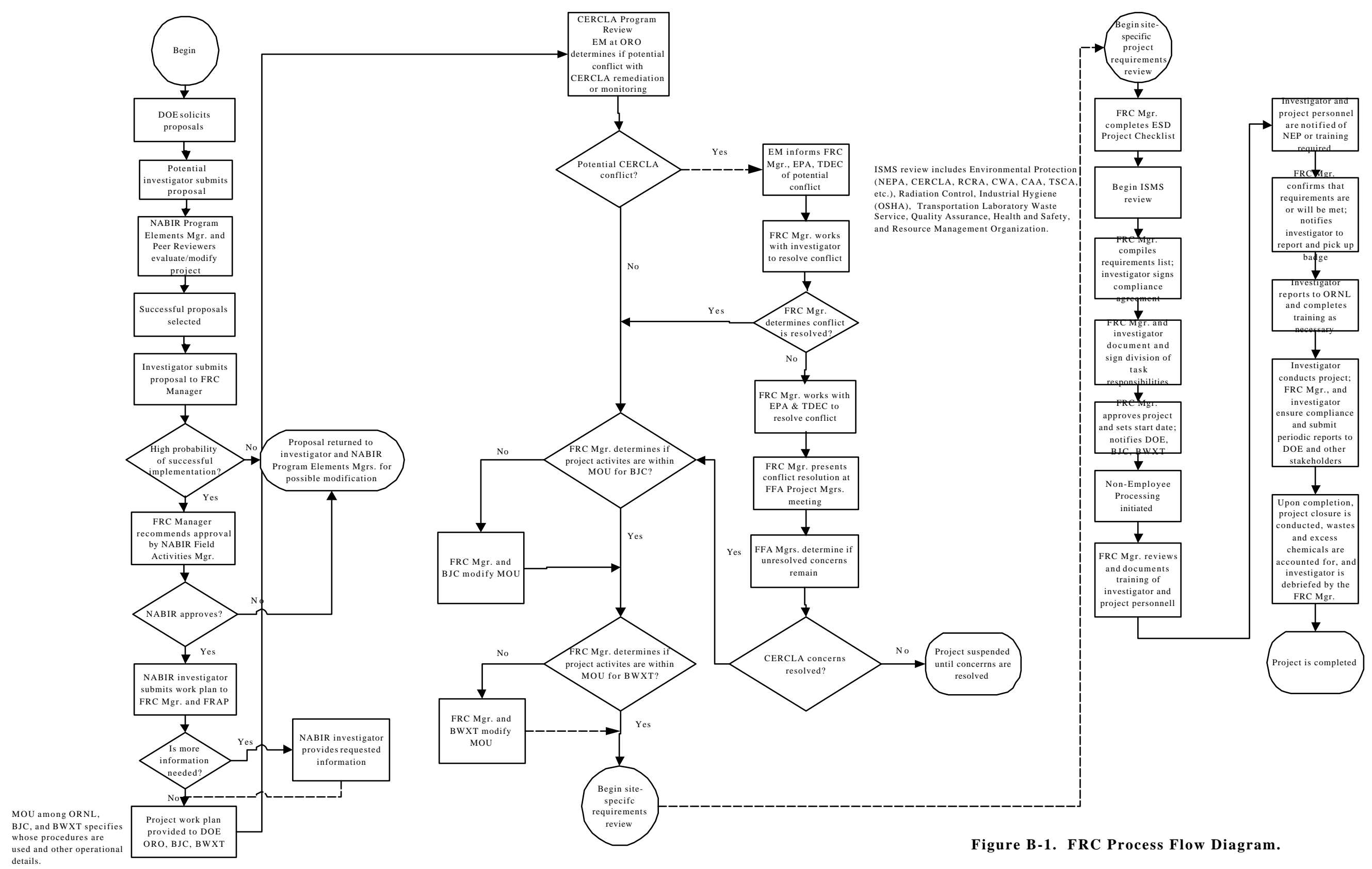


Appendix C

\section{PROJECT CHECKLISTS}

(Note: Checklists are subject to revision) 


\section{ESD ESH \& Q Project Evaluation}

Revised: August 14, 2000

Project Identification: (to be entered by ESH\&Q Group)

1. Date ESH\&Q Evaluation Submitted:

2. For identification of who is responsible for routine activities, complete information below. If special responsibilities must be assigned, i.e., air monitoring by OSHP, please identify those needs in your project discussion (see number 10).

Principal Investigator (PI): (It is the responsibility of the $P I$ to ensure that other staff members on this project are properly trained to the activities required by the project.)

Phone: Computer User ID:

Other Staff Members:

(It is the responsibility of the staff members to complete any training identified by the PI as needed for performance of activities required by the project.)

3. Title of Research:

4. Location of work (field site, Building, Room number):

5. Estimated Start Date: Estimated duration:

6. Does the project involve the design of items or systems including hardware and software items?(Ref: ORNLQA-P01, ORNL-QA-P02, OQS-QA-G08, OQS-QA-G09) Yes _ No _

7. Does this project require protection of information and property (proprietary, intellectual, property management)? (Ref: ORNL PM or TT Directives) Yes_No

8. Is this a paper or computer project (no lab/fieldwork)? Yes_No_ If "yes", your ESH\&Q Evaluation is complete. Although we must document this type of project in our files, NEPA review is not necessary. Please go to, complete, and sign SIGNATURE PAGE 6 and return division evaluation form to Monty Ross (1505/MS-6035).

9. Have you completed the NEPA Project Review Form? Projects must be reviewed by the ORNL NEPA Representative, James Hall (Building 6026C/MS-6395). (See ORNL-EP-001 NEPA/NHPA Compliance at ORNL)

If form has been completed, please attach copy of completed checklist. If not, do you need a copy of the form to send to James? Yes_ No _

If you have already turned in the form, please provide status information and/or identification number of the NEPA Review.

10. Please attach a description of the project to this form. We must have an operational description of project activities. (Include in the description how chemicals listed below will be used, (i.e., situations where materials will be heated or where gas, mists, vapor, or dust will be produced). Identify highly toxic or explosive chemicals and if waste generation will exceed $\mathbf{5 5}$ gallons.) For examples of hazards of concern, refer to No. 21. 


\section{ESD ESH \& Q Project Evaluation}

Revised: August 14, 2000

11. List chemicals to be used with information requested below. Attach page as needed. For help in determining toxicity or carcinogenicity, see ESD Chemical Hygiene Plan, Section 6 and Appendix D. MSDSs should match the chemical actually to be used (for example: powder, liquid, concentration, manufacturer). (Attach page if necessary.) 


\section{ESD ESH \& Q Project Evaluation}

Revised: August 14, 2000

RECID or

CAS \#

Chemical Name Concentration Quantity

Frequency Used To be used in a:

Min./Max. $\quad$ Hood Bench Biosafety

Top Cabinet

OSHA requires hazard controls must be reviewed annually. Initial here

and date

to document

this review has been done. Date should be 1 year after the date of the signature of the ESH\&Q Group reviewer on Signature Page (6).

12. Check the safety equipment needed to perform this research (Reference: ORNL-SH-P19).

\begin{tabular}{|c|c|c|}
\hline Eye Protection: & $\begin{array}{l}\text { _ Safety Glasses__ Goggles } \\
\text { _ Face Shield }\end{array}$ & Hearing Protection: \\
\hline
\end{tabular}

Gloves: _ _ Disposable: Vinyl, Latex, Nitrile: Dry Powders, Aqueous Solutions; Does NOT work forsolvents/corrosives

_ Neoprene (Black): Corrosives, solvents and alcohols

_ Nitrile (Blue or Green): Organic solvents (non-halogenated); puncture and abrasion resistant

_ Nomex or Zetex: Temperature extremes; Do NOT use Asbestos

_Butyl: Aldehydes, ketones, and esters

_ Viton TM: Chlorinated and aromatic solvents

- Other:

Brand:

Protective Clothing: _ Tyvec _ Khakis_Lab Coats (_White, _ Yellow)_Aprons_Safety Shoes

Respiratory Protection:

Respirator (Type:

) (Ref: ORNL-SH-P21)

Other special controls required:

13. Identify the isotopes to be used and fill in the requested information. (Attach page if necessary.)

*Operation: 1. Storage; 2. Very simple wet operation; 3. Normal chemical operation; 4. Complex wet operations with risk of spills and simple dry operation; 5 . Dry and dusty operation and those where isotopes are evolved as gases.

$\underline{\text { Radioisotope }} \stackrel{\text { Activity of }}{\text { Stock Sol'n }} \frac{\text { Activity of }}{\text { Working Sol'n }}$ Carrier Solution

Ci $\mathrm{Ci}$
Operation No.* (circle one)

$\begin{array}{lllll}1 & 2 & 3 & 4 & 5\end{array}$ 
ESD ESH \& Q Project Evaluation

Revised: August 14, 2000

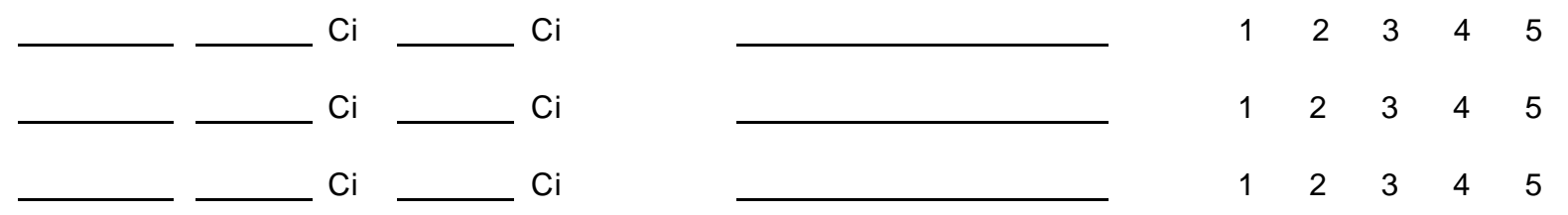




\section{ESD ESH \& Q Project Evaluation}

Revised: August 14, 2000

Stock solutions should be stored in the Isotope Storage Room (144A). Do you need authorization to work in that room? Yes _ No _ Where will working solutions be used and stored?

14. Does your project involve: movement of soil (Ref: ORNL-EP-P11) _ or use of animals or wildlife ${ }^{\star}$ ? Neither_

* ORNL is required by law and Federal/DOE mandates to ensure that personnel working with vertebrate animals be adequately trained in animal care and use through a mixture of experience, mentoring and formal training.

Please provide information concerning: a) where the soil originates (i.e. state, county, country) and how the soil will be used or b) species of animals. (Attach page if necessary.)

15. Does your project involve the use of polychlorinated biphenyls (PCB)? Yes _ No _

If "Yes", please provide information concerning how the PCB is being used. Note whether the work has been registered with Environmental Compliance. (REF: ORNL-EP-P04) (Attach page if necessary.)

16.Does your project involve transport of samples on public roads? Yes_ No _

17.Does your project involve excavation/penetration activities (Ref: ORNL-EP-P19, ENG-056)? Yes_ No _

18. Does your project involve underground injection* activities? Yes_No_

* The purpose of the UIC Permit Compliance Program is to ensure ORNL compliance with all applicable state and federal regulations associated with underground injection wells, which are regulated under the Safe Drinking Water Act (40 CFR 146 and TDEC Rule 1200-4-6).

19. Any new research sites on the reservation must be approved by RMO (Reservation Management Office) prior to initiating work. Is your project at a new research site? Yes_No_ If yes, have you contacted Pat Parr to facilitate moving your request through the process? Yes _ $\mathrm{No}_{-}$

20. Is this a RCRA Treatability study (Ref: ORNL-EP-P07)? Yes_ No _

RCRA Treatability Study - "A study in which a hazardous waste is subjected to a treatment proces sto determine:(1) whether the waste is amenable to the treatment process, (2) what pretreatment (if any) is required, (3) the optimal process conditions needed to achieve the desired treatment, (4) the efficiency of a treatment process for a specific waste or wastes, or (5) the characteristics and volumes of residuals from a particular treatment process."

Treatment - "Any method, technique, or process, including neutralization, designed to change the physical, chemical, or biological character or composition of any hazardous waste so as to neutralize such waste, or so as to recover energy or material resources from the waste, or so as to render such waste nonhazardous, or less hazardous; safer to transport, store, or dispose of; or amenable for recovery, amenable for storage, or reduced in volume."

21. Would the work activities involve any of the following ORNL procedures ("No" is the default answer.). It is important that you understand that you are to be aware of your responsibilities in the procedures marked below which pertain to this project. Pls must also ensure people working on their projects understand applicable responsibilities and requirements:

\section{A. BIOLOGICAL HAZARDS}

\section{PROCEDURES}

Biohazards

Yes_

ORNL-SH-P03 


\section{ESD ESH \& Q Project Evaluation}

Revised: August 14, 2000

Bloodborn Pathogens

\section{B. CHEMICAL HAZARDS}

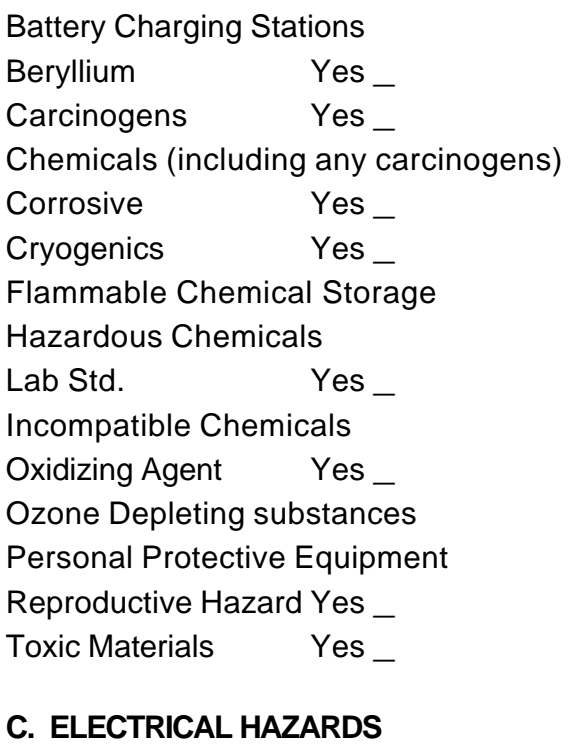

Electrical Hazards Yes_Lockout/Tagout of Hazardous Energy Use of Electrical Equipment High Voltage Power Tools Yes_-
Yes_-

\section{ENVIRONMENTAL PROTECTION}

$\begin{array}{lc}\text { Biological Waste } & \text { Yes__ } \\ \text { Clean Air Act } & \text { Yes__ } \\ \text { Clean Water Act } & \text { Yes__ } \\ \text { Hazardous/Mixed Waste } & \\ \text { Herbicides, Pesticides, Fungicides } \\ \text { Industrial Waste } \quad \text { Yes__ } \\ \text { Liquid Waste } & \text { Yes__ } \\ \text { NEPA Compliance } & \text { Yes_- } \\ \text { Polychlorinated Biphenyl (PCBs) } \\ \text { Solid Radioactive Waste } \\ \text { Regulated Medical Waste }\end{array}$

\section{E. PHYSICAL HAZARDS}

Blockage of Exits, Walkways, or Roadways

\section{Boating} Yes _

Compressed Gas Cylinders

Confined Space Entry Yes _

Cooling Towers, Work On or Near

Crane Operations, Forklift/Material Handling Equip.

Elevated Work

Yes_

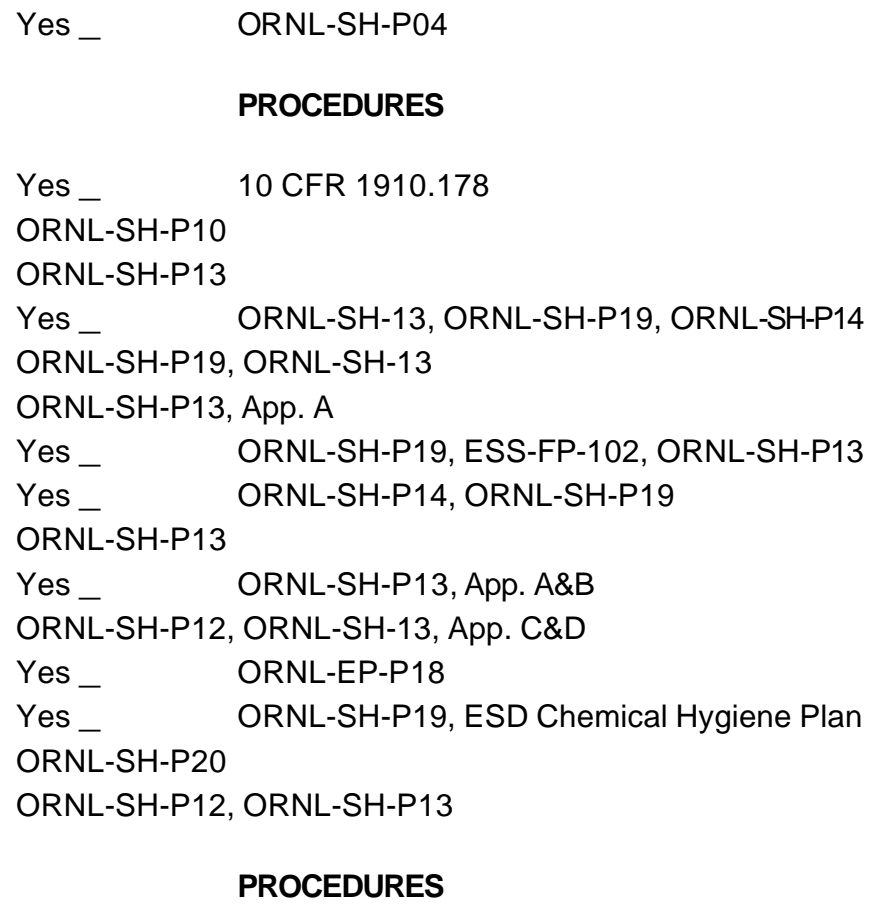

Yes

ORNL-SH-13, ORNL-SH-P19, ORNL-SH-P14

ORNL-SH-P19, ORNL-SH-13

ORNL-SH-P13, App. A

Yes _ ORNL-SH-P19, ESS-FP-102, ORNL-SH-P13

Yes__ ORNL-SH-P14, ORNL-SH-P19

ORNL-SH-P13

Yes _ ORNL-SH-P13, App. A\&B

ORNL-SH-P12, ORNL-SH-13, App. C\&D

Yes _ ORNL-EP-P18

Yes__ ORNL-SH-P19, ESD Chemical Hygiene Plan

ORNL-SH-P20

ORNL-SH-P12, ORNL-SH-P13

\section{PROCEDURES}

ORNL-SH-P25, ORNL-SH-P13, App.A

Yes _ ORNL-SH-P30

Yes _ ORNL-SH-P25, ORNL-SH-P13, App.A

ORNL-SH-P25, ORNL-SH-P13, App.A, ORNL-SH-P30

ORNL-SH-P25, ORNL-SH-P13, App.A, ORNL-SH-P39

\section{PROCEDURES}

ORNL-EP-P03

ORNL-EP-P02

ORNL-EP-P09

Yes

ORNL-WM-005, ORNL-EP-P01

Yes_

ORNL-EP-P14

ORNL-EP-P03

ORNL-WM-008

ORNL-EP-001

Yes

Yes_

ORNL-WM-005, ORNL-EP-P04

Yes

ORNL-WM-006

ORNL-EP-P03

\section{PROCEDURES}

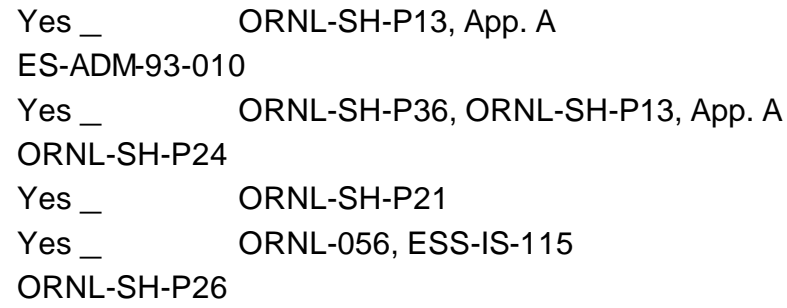




\section{ESD ESH \& Q Project Evaluation}

Revised: August 14, 2000

\begin{tabular}{|c|c|}
\hline Ergonomics & Yes_ \\
\hline Explosives & \\
\hline Firearm & \\
\hline \multicolumn{2}{|c|}{ Hazardous Waste Operations } \\
\hline Hazardous Equipment & \\
\hline Heat/Cold Stress & \\
\hline \multicolumn{2}{|l|}{ High Operating Pressures } \\
\hline Hoisting or Rigging Ope & \\
\hline
\end{tabular}

\section{E. PHYSICAL HAZARDS}

Lasers
Lifting - Manual $\quad$ Yes_-
Machine Guarding/Rotating Machinery or Tools
Needles/Sharps Yes_-
Noise ( 85 dBA) Yes_-
Pressurized Equipment
Job Hazard Evaluation
Respiratory Protection
Traffic Control - Pedestrian or Vehicular
Ventilation/Hoods Yes__

\section{F. RADIATION HAZARDS}

ESD Isotope Storage Room

Non-ionizing radiation

Radiological Area/Contamination Control

Radioactive Source Yes _

Radiation Generating Devices (X-ray mach.)

\section{G. TRANSPORTATION}

Shipment of hazardous \& nonhazardous Materials; Transportation and Packaging Safety Off-site shipment of Radioactive Materials Motor Carrier Safety Compliance at ORNL ORNL On-Site Transportation

\author{
ORNL-SH-P15 \\ ORNL-SH-P05, ORNL-SH-P13, App. A \\ ORNL-SH-P05, ES-ADM-92-008 \\ Yes \\ ORNL/M-2716 \\ ORNL-SH-P13, App. A \\ ORNL-SH-P22 \\ Yes \\ ORNL-SH-P35 \\ Yes_ \\ ORNL-SH-P28
}

\section{PROCEDURES}

\author{
ORNL-SH-P17 \\ ORNL-SH-P15 \\ Yes _ ORNL-SH-P39 \\ ORNL-SH-P13, App. A, ORNL-EP-P03 \\ ORNL-SH-P16 \\ Yes \\ ORNL-SH-P35 \\ Yes__ ORNL-SH-P29 \\ Yes__ ORNL-SH-P21 \\ Yes_ \\ ORNL-SH-23, ORNL-SH-P13, App. A
}

\section{PROCEDURES}

$\begin{array}{ll}\text { Yes_- } & \text { ES-ADM-91-004 } \\ \text { Yes_- } & \text { ORNL-SH-P18 } \\ \text { Yes__ } & \text { ORNL-RP-220, ORNL-RP-G1 } \\ \text { ORNL-RP-431 } & \\ \text { Yes__ } & \text { ORNL-RP-365 } \\ & \\ & \text { PROCEDURES }\end{array}$

$\begin{array}{ll}\text { Yes_- } & \text { ORNL-PT-001, ORNL-TS-002 } \\ \text { Yes_- } & \text { X-GP-20,21,22 } \\ \text { Yes__ } & \text { ORNL-TS-001 } \\ \text { Yes__ } & \text { ORNL/M-808 }\end{array}$

22. Price-Anderson Amendment Act Screening (P-AAA): To ensure compliance with P-AAA, ESD activities must be screened for their potential, either direct or indirect, of being P-AAA-related.

A) Does your work involve the use, storage, or disposal of radioactive material, the use of radiation generating devices, or exposure to ionizing radiation? Yes or No If yes, then the ORNL Radiological Directives as implemented in the ESD provide sufficient quality assurance for radiological activities.

B) Does your work in any way impact the safe operation of any radiological or nuclear facility or the staff or activities therein whether or not you use radioactive materials? Yes or No If yes, see below. 


\section{ESD ESH \& Q Project Evaluation}

Revised: August 14, 2000

C) Does your work relate to the design, analysis, manufacture, or assembly of items (hardware, equipment, or software) for use with radioactive material or radiation generating devices even if no radiological material is present? Yes or No

If either B or C is "yes", the requirements of ORNL-QA-P02, Nuclear Quality Assurance Program, must be applied to the process(es) related to radiological/nuclear safety using a graded approach appropriate for the level of risk.

Use option 2,3,or 4 on the following Signature Page to document how requirements of ORNL-QA-P02 are implemented within this project.

Non-compliances or occurrences associated with this project must be reported to the ESH\&Q Group for PAAA screening. 


\section{ESD ESH \& Q Project Evaluation}

Revised: August 14, 2000

\section{SIGNATURE PAGE}

The ESD QA Program and the ESD QA guidelines (presented in a generic laboratory QA plan format designed to be modified) are available from the ESD internal home page. ORNL QA directives and guidance are at http://www-internal.ornl.gov/ORNL/directives/data/qawss.htm. Links to additional QA-related guidance and tools and PAAA information are at http://www-internal.ornl.gov/OQPI/oqpi.htm.

Project QA - Please note that the option selected (1, 2, 3, or 4, below) establishes the QA requirements for a project. Project records provide the evidence of how well QA or management controls are implemented.

1. The ESD QA Program and ORNL-QA-P01, ORNL Quality Assurance Program, describe the minimum QA requirements for this project. (No further documentation needed.)

2. ___ Existing documentation, such as a QA plan, work plan, or procedure(s), that meets or exceeds the minimum requirements in option 1 establish the additional QA and management controls needed for this project. Briefly explain how this is documented.

3. Project needs more controls due to project complexity or risk of failure of one or more project component(s) (equipment failure, cost, scheduling). ORNL-QA-P01 plus the additional controls checked below will be used. If more documentation needs to be developed, choose option 4.

- Apply more control to the procurement of items and services. This could involve a more formality verification of supplier qualifications, defining and/or certifying specifications, establishing criteria for acceptance (of materials, equipment, services, systems, data, or other deliverables), reviewing performance or certification data, or ensuring suitability before use by performing inspections or other types of evaluations.

_ Develop written testing, inspection, or verification protocols (for materials, equipment, software, data, or other deliverables) for various stages of the project or a project activity.

_ Increase rigor in the management of materials, equipment, work processes, costs, scheduling, subcontracts, etc.

_ Implement a project-specific system for organizing, indexing, storing, protecting and controlling electronic media, documents, logbooks, data, records, or other information.

_ Implement a formal system for communicating new or changing requirements, regulations, and requests.

_ Implement a formal system for evaluating and improving project components and/or for reporting and correcting problems.

- Other:

4. _ A project-specific QA or management plan must be developed. A project-specific QA plan may be needed, for example, when a project is: complex; involves high risk processes for which failure would have serious consequences to safety or the project success; is subject to requirements from a regulatory agency, a national or international standard, or the sponsor.

\section{Project Identification \#}

\section{APPROVAL}

Principal Investigator: Date: Date:

The original, completed Project ESH\&Q Evaluation Form will be held in the ESH\&Q Office. Copies will be distributed to the $\mathrm{PI}$ along with the letter of approval. The Facility Manager and Section Head will receive copies of the approval letter.

(See next page for change notification form.) 


\section{ESD ESH \& Q Project Evaluation}

Revised: August 14, 2000

\section{Project Change Notification}

The page is to provide the Principal Investigator a mechanism to notify the ESD ESH\&Q Group of any changes that occur in the project between the date of approval and the two-year update. Examples of changes would include but are not limited to the following: project closure, changes in staff, introduction of hazard that was not previously reviewed, change in research location. This notification would not be used for changes that are inherent in the research process. Incorporation of safe practices in the research process is expected to address day-to-day changes.

We recommend making a copy of this page when submitting changes so that a blank form is available for future notifications.

Project Identification:

Date:

Principal Investigator (PI):

Phone: Computer User ID:

Title of Research:

Description of Change: 
ESD ESH \& Q Project Evaluation

Revised: August 14, 2000

\section{ORNL NEPA PROJECT REVIEW CHECKLIST}

(Revised 3/10/00)

\section{TOP SECTION FOR NEPA STAFF USE ONLY}

Date Received:

Project Number:

CX Cited:

File Name:

Project Title:

\begin{tabular}{|c|c|}
\hline Date: & \multicolumn{2}{|c|}{ Estimated Start Work Date: } \\
\hline $\begin{array}{c}\text { Project Engineer/Manager (Print } \\
\text { Name/Sign): }\end{array}$ & Bldg/MS/Phone/Fax No.: \\
\hline
\end{tabular}

Project Location (Plant, site, Area, Bldg. No.). Attach maps if appropriate.

\begin{tabular}{|l|l|}
\hline Facility Manager(s) Bldg/MS): & Division Representative (Bldg/MS): \\
\hline Division/Office: & Division/Office Director (Bldg/MS): \\
\hline Project Funding Category: & Check Funding Source: \\
LI_GPP_EXP_GPE__Other & DP_EM_ER_NE_TD_WM_Other \\
\hline Charge No. & FY 20 \\
\hline
\end{tabular}

1. ENVIRONMENTAL SUMMARY: Please answer $\mathrm{Y}$ (yes), $\mathrm{N}$ (no), or $\mathrm{U}$ (unknown) if your project generates, uses, or causes dis turbance to the following:

\begin{tabular}{|l|l|l|l|}
\hline 1. Air emissions & 14. Threatened and/or endangered species & \\
\hline 2. Liquid effluents & & 15. Clearing or excavation & \\
\hline 3. Floodplain disturbance & & 16. Activity outside area fence & \\
\hline 4. Wetland disturbance & & 17. Archeological/cultural resource & \\
\hline 5. Solid waste & & 18. Elevated noise levels & \\
\hline 6. Radioactive waste & & 19. Rad/haz substance chemical exposures & \\
\hline 7. Radioactive soil & & 20. Pesticide/herbicide use & \\
\hline 8. Hazardous or PCB waste & & 21. Explosive & \\
\hline 9. Mixed waste (rad. \& haz.) & & 22. Transportation issues & \\
\hline 10. Petroleum storage/use & & 23. Surface water & \\
\hline 11. Chemical storage/use & & 24. Groundwater & \\
\hline 12. Volatile/toxic/waste reactive & & 25. Undeveloped area & \\
\hline 13. Asbestos & & 26. Other & \\
\hline
\end{tabular}




\section{ESD ESH \& Q Project Evaluation}

Revised: August 14, 2000

2. PURPOSE AND NEED FOR PROPOSED ACTION: Provide background information that leads to the purpose and need for your project. State the purpose and need.

3. DESCRIPTION OF PROPOSED ACTION: Describe your project in detail providing as much specific information as possible. Is this a CERCLA action? If so, provide cost and time data. Include attachments where appropriate.

4. DESCRIPTION OF MATERIALS/WASTES: Describe the kinds and approximate amounts of wastes that would be generated and how they would be disposed of. 
ESD ESH \& Q Project Evaluation

Revised: August 14, 2000 
ESD ESH \& Q Project Evaluation

Revised: August 14, 2000

\section{ENVIRONMENTAL SAFETY AND HEALTH}

INSTRUCTION: The following is intended to provide information on the use of equipment, materials, etc., and activities that would be involved in the proposed project. Please answer each subject heading Y (yes) or N (no). If the subject is "Yes", check all applicable areas under the subject heading.

\begin{tabular}{|c|c|c|}
\hline INDUSTRIAL SAFETY? & RESPIRATORY & INDUSTRIAL HYGIENE \\
\hline $\mathrm{Y}-\mathrm{N}$ & $\begin{array}{l}\text { PROTECTION? } \\
\mathrm{Y} \quad \mathrm{N} \\
\end{array}$ & PROTECTION? Y _ _ N \\
\hline __ Excavation/Trenching/Clearing & __Abrasive Blasting & _High Noise Level \\
\hline _ Utilities Lockout/Tagout & _Acid or Alkali Cleaning of Metals & _Extreme Temperature \\
\hline _Crane Operations & _Degreasing & __Nonionizing Radiation \\
\hline _Welding/Cutting & _Decontamination & __Ergonomic Situations \\
\hline _Confined Space Entry & __Use of Coolant/Cutting Fluids & __Respirator/Other Air Purifying Device \\
\hline _Blocking of Plant Roads & _Welding, Cutting, or Brazing & __Anti-C Protective Clothes \\
\hline _Use of Scaffolds & __rinding, Polishing, Buffing & _Confined Space \\
\hline __Use of Corrosives & __ Metal Thermal Spraying & _Biohazards \\
\hline _Use of Incompatible Chemicals & __Painting & __Sanitation \\
\hline __Use of Compressed Gas Cylinders & __Electroplating & __other \\
\hline High Operating Pressures & __Metal Alloy Heat Treatment & \\
\hline __ X rays & _Boiler Deslagging & \\
\hline __Other Hazards & _Furnaces & \\
\hline & __Hoods & \\
\hline & ___Respirator/Other Air Purifying Device & \\
\hline & __other & \\
\hline EQUIPMENT? & RADIOLOGICAL AREAS? & RADIATION SOURCES? \\
\hline $\mathrm{Y} \_\mathrm{N}$ & $\mathrm{Y}$ & $\mathrm{Y}$ \\
\hline __Transformers & Area & __X-ray Machine/Generator \\
\hline _Capacitors & __Airborne Radioactivity Area & __Sealed Radioactive Material \\
\hline _Hydraulic Presses & __Radiation Area & __Accelerator \\
\hline $\begin{array}{l}\text { _-Other Hydraulic } \\
\text { Equipment }\end{array}$ & _Contamination Area & __Unsealed Radioactive Material \\
\hline __Large Light Ballasts & __Respirator Area & __other \\
\hline
\end{tabular}


ESD ESH \& Q Project Evaluation

Revised: August 14, 2000

\begin{tabular}{|l|l|l|}
\hline _Vacuum Pumps & _Other & \\
\hline _Other & & \\
\hline
\end{tabular}


ESD ESH \& Q Project Evaluation

Revised: August 14, 2000

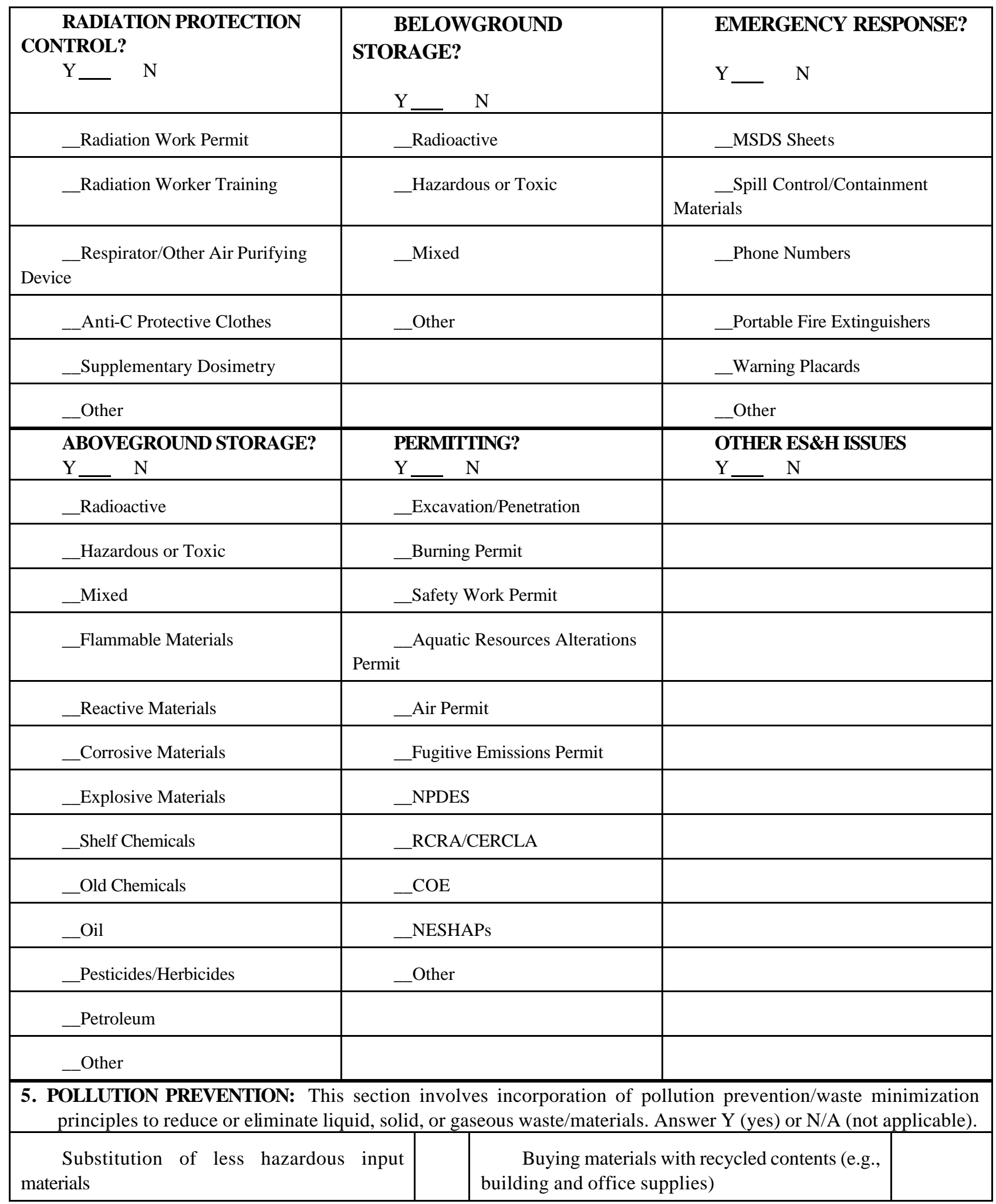




\section{ESD ESH \& Q Project Evaluation}

Revised: August 14, 2000

\begin{tabular}{|c|l|l|l|}
\hline $\begin{array}{c}\text { Improving operating practices (e.g., } \\
\text { inventory control, volume reduction, best } \\
\text { management practices) }\end{array}$ & $\begin{array}{c}\text { Purchasing energy- and water-efficient } \\
\text { equipment }\end{array}$ & \\
\hline $\begin{array}{c}\text { Selection of environmentally friendly (less } \\
\text { toxic) or longer-life products }\end{array}$ & $\begin{array}{c}\text { Segregating waste/material types (e.g., } \\
\text { hazardous, radiological, sanitary) }\end{array}$ & $\begin{array}{c}\text { Recycling materials off-site (e.g., scrap metal, } \\
\text { fluorescent light bulbs) }\end{array}$ & \\
\hline $\begin{array}{l}\text { Implementing process/technology changes } \\
\text { (e.g., equipment modifications) }\end{array}$ & $\begin{array}{c}\text { Reusing surplus materials on-site (e.g., } \\
\text { chemical exchange) }\end{array}$ & \\
\hline $\begin{array}{l}\text { Implementing in-process recycling (e.g., } \\
\text { solvent recovery) }\end{array}$ & & \\
\hline
\end{tabular}




\section{INTERNAL DISTRIBUTION}

1. S. G. Hildebrand, 1505, MS-6037

2-4. ESD Library

5. ORNL Central Research Library

6. ORNL Lab Records-RC

\section{ELECTRONIC NOTIFICATION}

7. H. D. Quarles, 1505, MS-6036

$8 . \quad$ D. B. Watson, 1505 , MS-6038 